Deriving nitrogen critical levels and loads based on the responses of acidophytic lichen communities on boreal urban Pinus sylvestris trunks

\title{
Manninen, Sirkku
}

2018-02-01

Manninen , S 2018 , ' Deriving nitrogen critical levels and loads based on the responses of acidophytic lichen communities on boreal urban Pinus sylvestris trunks ', The Science of the Total Environment, vol. 613-614 , pp. 751-762 . https://doi.org/10.1016/j.scitotenv.2017.09.150

http://hdl.handle.net/10138/310804

https://doi.org/10.1016/j.scitotenv.2017.09.150

cc_by_nc_nd

acceptedVersion

Downloaded from Helda, University of Helsinki institutional repository.

This is an electronic reprint of the original article.

This reprint may differ from the original in pagination and typographic detail.

Please cite the original version. 
1 Deriving nitrogen critical levels and loads based on the responses of acidophytic lichen 2 communities on boreal urban Pinus sylvestris trunks

3

$4 \quad$ Sirkku Manninen*

5 Department of Environmental Sciences, University of Helsinki, P.O. Box 65 (Viikinkaari 2a),

600014 Helsinki, Finland

7 Email: sirkku.manninen@helsinki.fi

8 Tel. +358294159101

9

$10 *$ corresponding author 


\section{Abstract}

12 The deposition of reactive nitrogen $(\mathrm{N})$ compounds currently predominates over sulphur (S)

13 deposition in most of the cities in Europe and North America. Acidophytic lichens growing 14 on tree trunks are known to be sensitive to both $\mathrm{N}$ and $\mathrm{S}$ deposition. Given that tree species 15 and climatic factors affect the composition of epiphytic lichen communities and modify lichen 16 responses to air pollution, this study focused on the impact of urban air pollution on 17 acidophytes growing on boreal conifer trunks. The study was performed in the Helsinki 18 metropolitan area, southern Finland, where annual mean nitrogen dioxide $\left(\mathrm{NO}_{2}\right)$ 19 concentrations range from $4--5 \mu \mathrm{g} \mathrm{m}^{-3}$ to $>50 \mu \mathrm{g} \mathrm{m}^{-3}$. In addition, background forest sites in 20 southern and northern Finland were included. The results demonstrated elevated $\mathrm{N}$ contents $21(\geq 0.7 \%)$ in Hypogymnia physodes and Platismatia glauca at all the sites where the species 22 occurred. In the Helsinki metropolitan area, a higher frequency of green algae + 23 Scoliociosporum chlorococcum and reduced numerical frequencies of other indicator lichen 24 species (e.g. Pseudevernia furfuracea, Bryoria spp., Usnea spp.) were associated with 25 elevated atmospheric concentrations of $\mathrm{NO}_{2}$ and particulate matter containing $\mathrm{N}$, as well as elevated concentrations of inorganic $\mathrm{N}$ in bark. The $\mathrm{N}$ isotope values $\left(\delta^{15} \mathrm{~N}\right)$ of lichens supported the uptake of oxidized N mainly originating from road traffic. Sulphur dioxide $\left(\mathrm{SO}_{2}\right)$ also negatively affected the most sensitive species, despite the current low levels (1--4 $\left.\mu \mathrm{g} \mathrm{m}^{-3} \mathrm{yr}^{-1}\right)$. Critical levels of $5 \mu \mathrm{g} \mathrm{NO}_{2} \mathrm{~m}^{-3} \mathrm{yr}^{-1}$ and $0.5 \mu \mathrm{g} \mathrm{NH}_{3} \mathrm{~m}^{-3} \mathrm{yr}^{-1}$, and a critical load of 2--3 $\mathrm{kg} \mathrm{N} \mathrm{ha}^{-1} \mathrm{yr}^{-1}$ are proposed for protecting the diversity of boreal acidophytes. This study calls for measurements of the throughfall of various $\mathrm{N}$ fractions in urban forest ecosystems along precipitation and temperature gradients to verify the proposed critical levels and loads. 


\section{Introduction}

Lichens consist of nutritionally specialized mycobionts (fungi) living in symbiosis with photobionts (unicellular algae or cyanobacteria or both) (Honegger, 1998). The development of epiphytic lichen communities on tree trunks is determined by various environmental factors, including the degree of illumination and humidity of the environment, age and $\mathrm{pH}$ of the bark surface, continuity and age of woodland cover at a particular site and air pollution (Giordani et al., 2014; Hauck, 2011). Rootless, poikilohydric epiphytic lichens with green algae as photobionts are solely dependent on the atmosphere, throughfall and stemflow as sources of nutrients, including nitrogen (N) (Honegger, 1991; Nieboer et al., 1978; Palmqvist et al., 2002). Elements deposited on the lichen surface are transferred as dissolved ions into the fungal cells via the hyphae cortex (Honegger, 1993). The decline of epiphytic lichens in areas affected by anthropogenic emissions of air pollutants has particularly been attributed to the effective uptake of sulphuric acid $\left(\mathrm{H}_{2} \mathrm{SO}_{4}\right)$ and sulphate $\left(\mathrm{SO}_{4}{ }^{2-}\right)$ derived from sulphur dioxide $\left(\mathrm{SO}_{2}\right)$ under humid conditions, leading to morphological and physiological changes in the photosynthesizing algal layers (Rao and Leblanc, 1966). The toxicity of sulphur (S) compounds is dependent on the buffering capacity of both the substrate and the lichen (Skye, 1968).

The cyanobacterial lichen Lobaria pulmonaria may only occur in areas where the annual mean $\mathrm{SO}_{2}$ concentration is $<5 \mu \mathrm{g} \mathrm{m}^{-3}$ (Denison et al., 1977). It is generally agreed that Usnea, Bryoria, Ramalina and Evernia species are also sensitive to air pollution, especially $\mathrm{SO}_{2}$ (Gilbert, 1973). However, S pollution is no longer a major threat to lichens in Europe, given that $\mathrm{SO}_{2}$ emissions, concentrations of $\mathrm{SO}_{2}$ and aerosol $\mathrm{SO}_{4}{ }^{2-}$, and $\mathrm{S}$ deposition have decreased by $70--90 \%$ in Europe since 1980, as a result of the United Nations Economic Commission for Europe (UNECE) Convention on Long Range Transboundary Air Pollution (CLTRAP). For comparison, the concentrations of oxidized and reduced $\mathrm{N}$ compounds in the air and precipitation have only decreased by about 25\% since 1990 (Tørseth et al., 2012).

Besides $\mathrm{SO}_{2}$, nitrogen dioxide $\left(\mathrm{NO}_{2}\right)$ has been ranked as a more important factor determining lichen biodiversity than heavy metals in particulate matter (PM) (van Dobben et al., 2001). The current high diversity of epiphytic lichens in cities such as London, UK, with high $\mathrm{N}$ emissions from vehicles, is apparently associated with both reduced $\mathrm{SO}_{2}$ emissions and high concentrations of nitrogen oxides $\left(\mathrm{NO}_{\mathrm{x}}\right)$ (Davies et al., 2007; Larsen et al., 2007; Purvis et al., 2003). For instance, Davies et al. (2007) attributed the positive relationship between ambient concentrations of $\mathrm{NO}_{\mathrm{x}}$ and lichen abundance on Fraxinus excelsior trunks to 
nitrophytes has also occurred in all parts of the Netherlands with a high cattle density, especially on deciduous trees with acid bark, such as Quercus and Fagus. In the same period, several species that prefer or require acid bark, such as Evernia prunastri, Hypogymnia physodes and Pseudevernia furfuracea, have rapidly decreased in abundance (van Herk, 1999). A rapid decrease in the acidophyte Lecanora conizaeoides in Europe has also been attributed to its sensitivity to ammonia $\left(\mathrm{NH}_{3}\right)$, as well as decreasing $\mathrm{SO}_{2}$ concentrations. This suggests that some acidophytes are sensitive to both a rise in bark $\mathrm{pH}$ and an increase in the ammonium $\left(\mathrm{NH}_{4}{ }^{+}\right)$content of the bark (van Herk, 1999, 2001).

In Europe, the empirical critical level (CLE) of $\mathrm{NH}_{3}$ for epiphytic lichens is $1 \mu \mathrm{g} \mathrm{m}^{-3} \mathrm{yr}^{-1}$ and that of $\mathrm{NO}_{2}$ for sensitive vegetation and ecosystems $30 \mu \mathrm{g} \mathrm{m}^{-3} \mathrm{yr}^{-1}$ (Cape et al., 2009; CLTRAP, 2017). A critical load (CLO) of 5--10 kg N ha $\mathrm{yr}^{-1}$ is applied for European pine taiga woodland (Bobbink and Hettelingh, 2011; de Vries et al., 2007). However, Giordani et al. (2014) recently determined a CLO of $2.4 \mathrm{~kg} \mathrm{~N} \mathrm{ha}^{-1} \mathrm{yr}^{-1}$ for European forests by means of epiphytic lichens. Supporting this, a CLO of 1--3 $\mathrm{kg} \mathrm{N} \mathrm{ha}^{-1} \mathrm{yr}^{-1}$ for the protection of the tundra and taiga lichen flora was determined in the United States, based on changes in lichen pigment physiology, abundance and/or community composition (Pardo et al., 2011a). A model used by Geiser et al. (2010) in turn generated a CLE of $0.51 \mu \mathrm{g} \mathrm{m}^{-3}$ for the mean annual concentration of $\mathrm{N}$ in ambient-air fine particulates. The lower CLE and CLO values proposed by North American researchers may partly be attributed to the fact that there are still pristine baseline ecosystems in the United States, while in Europe there are none due to considerably higher $\mathrm{N}$ deposition over many decades (Pardo et al., 2011b).

Conifers with acid bark, such as Picea abies and Pinus sylvestris (Kuusinen, 1996), predominate in the boreal zone (Ahti, 1977). Their bark supports the occurrence of acidophytic lichens, which are only able to tolerate low $\mathrm{N}$ concentrations or doses (GaioOliveira et al., 2001, 2005). Given the great abundance of larger-sized foliose and fruticose lichens on P. sylvestris trunks in relatively sparse northern boreal forests (Bäcklund et al., 2016), the oligotrophic lichen community on P. sylvestris trunks may be considered as a good indicator of atmospheric N pollution. Supporting this, Giordani et al. (2014) reported that air pollutant effects on lichens are particularly evident in European nemoral/boreal coniferous forests. Important lichen species on non-eutrophicated conifer bark, even in urban environments in the boreal zone, include H. physodes, Parmeliopsis ambigua, Platismatia

101 glauca, P. furfuracea and Tuckermannopsis chlorophylla (formerly Cetraria chlorophylla) 102 (Ahti, 1977). 
Studies on the effects of air pollution on epiphytic lichens in Helsinki, Finland, date back to the 1930s, when Vaarna (1934) reported a lichen desert in the city centre, with only green algae (Protococceae) occurring on the trunks and branches of both deciduous and coniferous trees. Outside the lichen desert, the small thalli of Xanthoria parietina on Acer, Tilia and Ulmus were green or greyish green, while the thalli of Parmelia sulcata often appeared to become reddish under exposure to elevated $\mathrm{NH}_{3}$. Species found on $P$. sylvestris included Hypocenomyce scalaris, H. physodes, P. ambigua and Parmeliopsis hyperopta, P. furfuracea, T. chlorophylla and Vulpicida pinastri. For instance, Usnea hirta was only occasionally observed. The responses were attributed to road dust, soot, $\mathrm{NH}_{3}$ and other gaseous emissions from industry, domestic heating and traffic, including railroads and horse faeces (Vaarna, 1934). Recently, negative effects of $\mathrm{NO}_{\mathrm{x}}$ on the bryophyte Pleurozium schreberi, together with changes in forest vegetation and a reduced soil C:N ratio, have suggested $\mathrm{N}$ saturation of the urban forests in the Helsinki metropolitan area (Manninen et al., 2013).

This field study was motivated by the fact that the lichen community on $P$. sylvestris trunks in Helsinki city centre appeared not to have recovered (personal observation), despite a decrease in annual mean $\mathrm{SO}_{2}$ concentrations from 50--100 $\mu \mathrm{g} \mathrm{m}^{-3}$ in the $1950 \mathrm{~s}$ and $1960 \mathrm{~s}$ (Taipale, 2006), and still 30--70 $\mu \mathrm{g} \mathrm{m}^{-3}$ in 1970, to current concentrations of 1--4 $\mu \mathrm{g} \mathrm{m}^{-3}$ (Kaski et al., 2016). While the $\mathrm{SO}_{2}$ concentrations are below the CLE of $20 \mu \mathrm{g} \mathrm{m}^{-3} \mathrm{yr}^{-1}$ for forest vegetation and $10 \mu \mathrm{g} \mathrm{m}^{-3} \mathrm{yr}^{-1}$ for cyanobacterial lichens (Ashmore and Wilson, 1993; CLTRAP, 2017), the CLE of $30 \mu \mathrm{g} \mathrm{NO}_{2} \mathrm{~m}^{-3} \mathrm{yr}^{-1}$ is exceeded in the city centre and close to the main streets and highways (Hannuniemi et al., 2016; Kaski et al. 2016). Moreover, when $H$. physodes occurs on the trunks of $P$. sylvestris in the city centre, the small wrinkled thalli are dark greyish green in colour (personal observation). This suggests eutrophication of the environment due to increased emissions of $\mathrm{NH}_{3}$ from vehicles with three-way catalysts (Cape et al., 2004; Sutton et al., 2000).

There is little data on $\mathrm{N}$ deposition in urban areas, although urban ecosystems may experience atmospheric deposition of reactive $\mathrm{N}$ compounds, which is manifold compared to that at regional and national monitoring sites in remote areas (Lovett et al., 2000; Rao et al., 2014; Redling et al., 2013). This is because the pollution monitoring devices located in background areas do not capture the local dry deposition of various gaseous $\mathrm{N}$ compounds (Braun et al., 2017), including $\mathrm{NO}_{\mathrm{x}}$ from urban automobiles (Elliot et al., 2007, 2009). Moreover, Karl et al. (2017) demonstrated that traffic-derived atmospheric $\mathrm{NO}_{\mathrm{x}}$ emissions in Europe apparently are appreciably underestimated. Consequently, the models used to spatially predict estimates of $\mathrm{N}$ deposition based on emission data or established deposition collectors 
137 with limited spatial cover underestimate the rates of $\mathrm{N}$ deposition in and near cities, especially

138 if the networks do not even measure all of the components that can be deposited (Howarth,

139 2007; Rao et al., 2014; Redling et al., 2013; Root et al., 2013).

140 Our understanding of $\mathrm{N}$ deposition and its effects on epiphytic lichens under various 141 climatic conditions, and especially in urban ecosystems, may also be biased due to the fact 142 that in Europe, knowledge of N-related changes in epiphytic lichen communities mainly 143 comes from studies on species growing on deciduous trees in areas with high long-term 144 emissions of $\mathrm{NH}_{3}$ (see e.g. van Herk, 1999 and references therein). Munzi et al. (2014) 145 recently highlighted the need to establish CLEs for $\mathrm{NH}_{3}$ based on oligotrophic lichen species instead of $\mathrm{N}$-tolerant species (see also Jovan et al., 2012). It has also been suggested in terms of $\mathrm{N}$-deposition effects in boreal forests that the overall quantity of $\mathrm{N}$ deposited does not solely determine lichen responses, because the ratio of nitrate $\left(\mathrm{NO}_{3}{ }^{-}\right)$to $\mathrm{NH}_{4}{ }^{+}$in deposition may change the CLO thresholds and the nature of effects on lichens (Bobbink et al., 2010;

150 Giordani et al., 2014). In addition to changes in species composition, pollutant contents of 151 lichen thalli have been used as indicators for exceedance of N CLOs. For instance, Fenn et al. 152 (2008) suggested that $1.0 \%$ of the $\mathrm{N}$ in Letharia vulpina may indicate exceedance of the $\mathrm{N}$ 153 threshold of $3.1 \mathrm{~kg} \mathrm{ha}^{-1} \mathrm{yr}^{-1}$.

154 This study was performed in the Helsinki metropolitan area, southern Finland, where the daily numbers of cars reach up to 90 000--110 000 on the busiest dual carriageways leading into and out of the city centre and on ring roads (City of Helsinki; Finnish Transport Agency).

157 It was hypothesized that i) air pollution still negatively affects corticolous lichens in the 158 Helsinki metropolitan area and ii) the lichen responses observed are mainly associated with $159 \mathrm{NO}_{\mathrm{x}}$ and/or $\mathrm{NH}_{3}$ emissions from vehicles (Davies et al., 2007 and references therein). To test 160 the hypotheses, occurrence of selected indicator species on conifer trunks was scored and 161 lichens were collected for analysis of carbon (C) and N contents. Lichens were also analysed 162 for the isotopic composition of $\mathrm{N}$ to assess the role of oxidized versus reduced $\mathrm{N}$ emissions 163 (Bermejo-Orduna et al., 2014; Pearson et al., 2000). Bark chemical characteristics (Schultz et 164 al., 1997, 1999), and available air quality data were used as anthropogenic environmental 165 drivers in the statistical analyses.

\section{Material and methods}

\subsection{Field sites}


170 The total number of study sites was 44. Thirty-eight of the sites were located at distances of $171 \quad 1.6--30 \mathrm{~km}$ from the city centre in the metropolitan area of Helsinki $\left(60^{\circ} 10^{\prime} \mathrm{N}, 24^{\circ} 56^{\prime} \mathrm{E}\right)$ (Fig.

172 1). Three sites in Teijo National Park $\left(60^{\circ} 13^{\prime} \mathrm{N}, 22^{\circ} 57^{\prime} \mathrm{E} ; 140 \mathrm{~km} \mathrm{~W}\right.$ from Helsinki) served as 173 southern Finnish background controls. In addition, three sites in Pallas National Park $\left(68^{\circ} 4^{\prime} \mathrm{N}\right.$, $1742^{\circ} 3^{\prime} \mathrm{E} ; 890 \mathrm{~km} \mathrm{~N}$ from Helsinki), from where air quality and deposition data were available, 175 were used as remote background controls. The fieldwork was performed from 13 June to 15 176 July 2016 in the Helsinki metropolitan area and Teijo, and from 20 to 22 September 2016 in 177 Pallas.

178 The environmental conditions in terms of climate, air quality and/or deposition for the 179 Helsinki metropolitan area and Pallas are presented in Table 1. The annual means for total $180 \mathrm{NO}_{2}$, total $\mathrm{SO}_{2}$ and total $\mathrm{PM}_{2.5}$ (particulate matter, $\mathrm{PM}<2.5 \mu \mathrm{m}$, includes $\mathrm{SO}_{4}{ }^{2-}, \mathrm{NO}_{3}{ }^{-}$and $181 \mathrm{NH}_{4}{ }^{+}$aerosols) concentrations for the sites in the Helsinki metropolitan area were derived 182 from modelled dispersal maps of emissions from road traffic, energy production, shipping and 183 aircraft provided by the Finnish Meteorological Institute (Hannuniemi et al., 2016) and 184 measurements by the Helsinki Region Environmental Services Authority (Kaski et al., 2016). 185 The variation in annual mean concentrations is greatest for total $\mathrm{NO}_{2}$ due to emissions from 186 road traffic, while the highest total $\mathrm{SO}_{2}$ concentrations occur close to harbours in the city 187 centre (Hannuniemi et al., 2016; Kaski et al., 2016). The largest coal power plants are also 188 located in the city centre by the sea (Fig. 1). The total $\mathrm{PM}_{2.5}$ concentrations are mainly 189 associated with road traffic and domestic wood burning and vary from the local/regional 190 background of $6.5 \mu \mathrm{g} \mathrm{m}^{-3} \mathrm{yr}^{-1}$ to $>9 \mu \mathrm{g} \mathrm{m}^{-3} \mathrm{yr}^{-1}$ at the busiest roundabouts (Hannuniemi et al., 191 2016). While the $\mathrm{SO}_{4}-\mathrm{S}$ concentrations in both bulk deposition and throughfall have 192 decreased since the late 1990s in background areas in southern Finland, no such trends have 193 been observed for $\mathrm{NO}_{3}{ }^{-}-\mathrm{N}$ or $\mathrm{NH}_{4}{ }^{+}-\mathrm{N}$ (Lindroos et al., 2013; Ruoho-Airola et al., 2015). In 194 fact, N deposition has been increasing in Finnish Lapland since the mid-1990s (Ruoho-Airola 195 et al., 2015). 


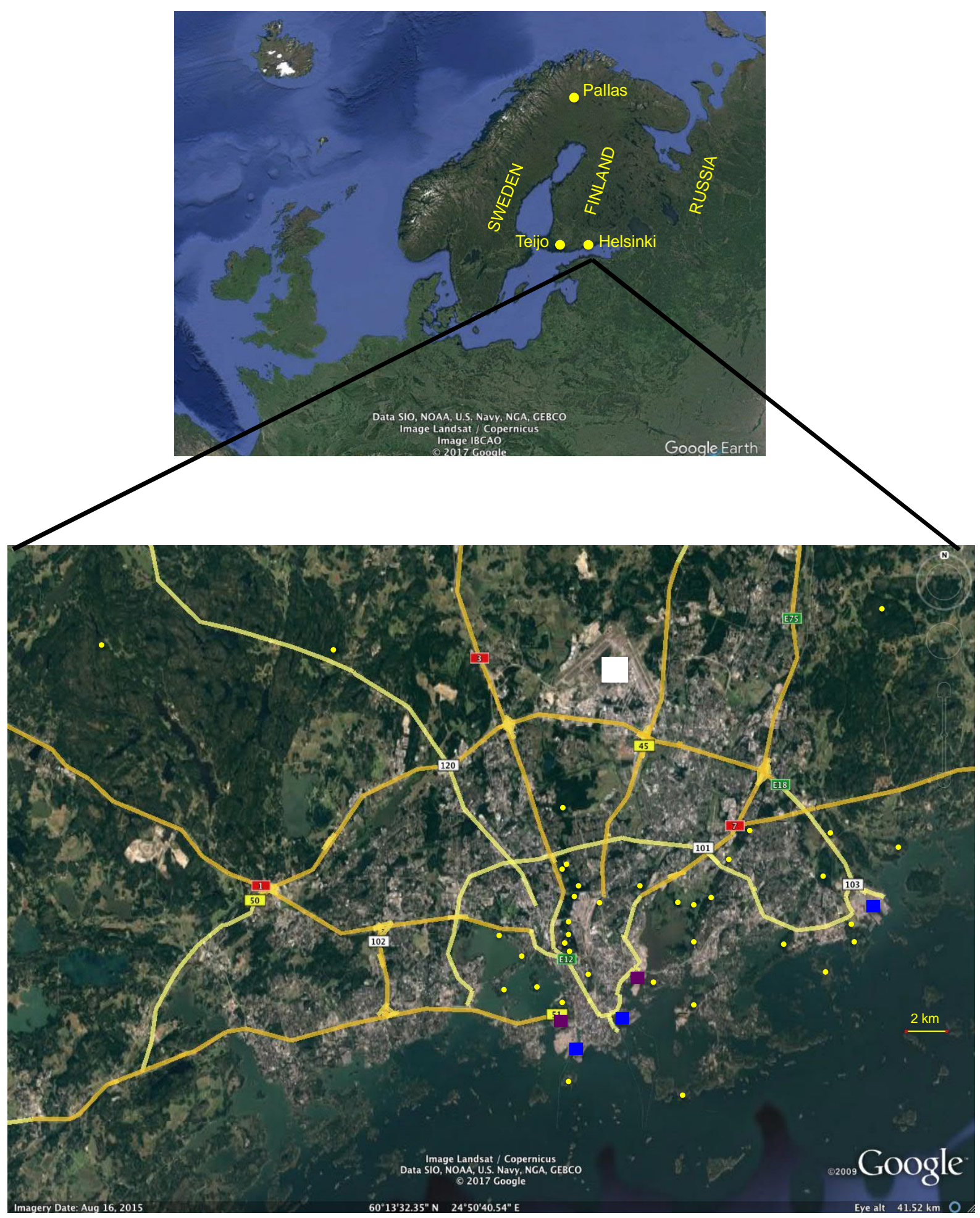

Fig. 1. Locations of the study sites (yellow dots), the largest coal power plants (purple squares), harbours (blue squares) and Helsinki-Vantaa airport (white square) in the Helsinki metropolitan area (lower map). The main roads are indicated with their national or European numbers. Locations of the background control areas in Teijo and Pallas National Parks are also indicated in the upper map. 
Table 1. Temperature, precipitation, air quality, and nitrogen $(\mathrm{N})$ and sulphur $(\mathrm{S})$ deposition in 206 Helsinki city centre and a remote background area in northern Finland (Pallas) (Finnish 207 Meteorological Institute, Air Quality in Finland and Temperature and precipitation statistics 208 from 1961 onwards; Flechard et al., 2011; Hannuniemi et al., 2016; Kaski et al., 2016; Ruoho209 Airola et al., 2015).

\subsection{Species frequencies}

The Finnish standard for mapping air quality with the help of commonly occurring dominant, Total concentrations of $\mathrm{NO}_{2}, \mathrm{SO}_{2}$ and $\mathrm{PM}_{2.5}$ derived from modelled dispersal maps of emissions from road traffic, energy production, shipping and aircraft generalist, epiphytic lichen species on P. sylvestris trunks (Suomen standardisoimisliitto, 1990) was used. At each site (approx. $200 \mathrm{~m}^{2}$ ), with P. sylvestris usually being the only tree species, five trees typical of the site (diameter at breast height, $\mathrm{DBH} \geq 20 \mathrm{~cm}$; branchless up to at least $3 \mathrm{~m}$ ) were selected for scoring of the lichens. The average canopy cover of $P$. sylvestris was visually assessed and the average height using a clinometer. DBH was separately measured for each of the five trees used for lichen scoring.

The frequencies of 12 indicator species $(0=$ absent or $1=$ present $)$ were scored at heights of 100--200 cm, i.e. resulting in a frequency of 0--5 for each species per site. The species were $H$. physodes, $P$. ambigua, $P$. hyperopta \& Imshaugia aleurites, $H$. scalaris, Bryoria spp., 
Usnea spp., P. glauca, V. pinastri, P. furfuracea, T. chlorophylla, P. sulcata, and green algae + Scoliciosporum chlorococcum. The frequencies of lichen species were not scored in Pallas, because species such as $P$. glauca and $P$. furfuracea, which are common in the southern subzones of the boreal zone, are rare in the northernmost parts of Fennoscandia (Ahti, 1977; Hale, 1968; Thell and Moberg, 2011).

\subsection{Lichen chemistry}

Hypogymnia physodes, $P$. glauca and/or P. furfuracea were collected for analysis of $\mathrm{C}$ and $\mathrm{N}$ contents and the isotopic composition of $\mathrm{N}\left(\delta^{15} \mathrm{~N}\right)$ from the trunks of trees that heen scored for lichen frequencies. For each species, a pooled sample from the trunks of 2--5 trees was collected, depending on the frequency of thalli. At three sites out of the 38 in the Helsinki metropolitan area, the thalli of $H$. physodes were absent, and at one site they were so few and stunted that samples could not be collected. Platismatia glauca could be sampled from six out of eight sites where the species grew, and P. furfuracea from 10 sites out of 11 . In Teijo, samples of each of the three species were collected from each site, while in Pallas only $H$. physodes was collected, because the two other species did not grow at the sites.

The $\mathrm{C}$ and $\mathrm{N}$ contents (w/w) of air-dried, ground samples were analysed using hightemperature combustion (Vario MAX CN analyser, Elementar Analysensysteme GmbH, Langenselhold, Germany) at the Department of Forest Sciences, University of Helsinki. The isotopic composition of $\mathrm{N}$ was measured on a Thermo Finnigan Delta ${ }^{\text {Plus }}$ Advantage isotoperatio mass spectrometer (ThermoFischer Scientific, Waltham, MA, USA) coupled to an NC 2500 elemental analyser. All samples were analysed in duplicate. Typical reproducibility $(1 \sigma)$, estimated from repeated measurements of in-house reference material and sample replicates, was $\pm 0.3 \%$. The isotopic values, normalized using International Atomic Energy Agency (IAEA)-certified isotopic reference materials, are reported in delta $(\delta)$ notation, relative to the international standards AIR (N). Analysis of the isotopic composition of $\mathrm{N}$ was performed in the Laboratory of Chronology, Finnish Museum of Natural History - LUOMUS, University of Helsinki.

275

\subsection{Bark chemistry}

277 Bark flakes ( $<3 \mathrm{~mm}$ in thickness) were taken at a height of approximately $1.5 \mathrm{~m}$ from the 278 trunks of the same trees used for scoring of the lichen frequencies. The samples were cleaned of lichens, air-dried and ground ( $\leq 1 \mathrm{~mm}$ particle size). Five grams of bark was mixed with 50 
$\mathrm{ml}$ of deionized water and measured after $24 \mathrm{hr}$ for conductivity (Jenway 4010 Conductivity Meter, Cole-Parmer, Stone, Staffordshire, UK) and pH (Inolab Level 1).

For the nitrite + nitrate $\left(\mathrm{NO}_{2}{ }^{-}+\mathrm{NO}_{3}{ }^{-}\right)$and $\mathrm{NH}_{4}{ }^{+}$analyses, $10 \mathrm{ml}$ of deionized water was added to $0.5 \mathrm{~g}$ of ground bark. The samples were vigorously shaken by hand, left for $30 \mathrm{~min}$, shaken again, centrifuged for $5 \mathrm{~min}$ at 4000 revolutions per minute (rpm) (Wolterbeek et al., 1996) and filtered through a $0.45-\mu \mathrm{m}$ Millipore filter (Millex HA, cellulose esters; Merck $\mathrm{KGaA}$, Darmstadt, Germany). The $\mathrm{NO}_{2}{ }^{-}+\mathrm{NO}_{3}{ }^{-} \mathrm{N}$ and $\mathrm{NH}_{4}{ }^{+}-\mathrm{N}$ concentrations were measured with a Thermo Scientific Gallery Plus Automated Photometric Analyser at the Lammi Biological Station, University of Helsinki, following standard methods (SFS-EN International Organization for Standardization (ISO) 13395 and SFS-EN ISO 11732).

The S content of bark was measured with a Thermo Scientific iCAP 6000 series inductively coupled plasma (ICP) optic emission spectrometer. Sample preparation followed Environmental Protection Agency (EPA) Method 3051 (Microwave Assisted $\mathrm{HNO}_{3}$ Digestion). The analyses were performed at the Department of Forest Sciences, University of

294 Helsinki.

\subsection{Statistical analyses}

297 The data were checked for normality prior to the analyses. Differences in site characteristics, and bark and lichen chemistry between the Helsinki metropolitan area, Teijo and/or Pallas, as well as differences between lichen species were analysed with the Student's t-test or MannWhitney U-test. The relationships between the variables were examined with the Spearman rank correlation test or Pearson correlation test and principal component analysis (PCA) (varimax rotation with Kaiser normalization). The lichen and bark elemental data were logtransformed for the analyses. The results were considered significant at $\mathrm{p} \leq 0.05$ and as trends at $\mathrm{p} \leq 0.1$ Statistic analysis was performed using IBM SPSS Statistics 24.0 for Mac (IBM Corp., Armonk, NY, USA).

\section{Results}

\subsection{Bark chemistry and other site characteristics}

310 In the Helsinki metropolitan area, the canopy cover was negatively correlated with the 311 distance from the city centre and positively with air-pollution variables, such as the 312 atmospheric concentrations of total $\mathrm{NO}_{2}$ and total $\mathrm{PM}_{2.5}$ (Table 3). The trees close to the city 313 centre also had the greatest DBH, i.e. the correlation between DBH and canopy cover was 
314 statistically significant $\left(\mathrm{r}_{\mathrm{S}}=0.38, \mathrm{p}=0.018, \mathrm{n}=38\right)$. The annual mean concentrations of total

$315 \mathrm{NO}_{2}$, total $\mathrm{PM}_{2.5}$ and $\mathrm{NO}_{2}$ derived from road traffic were positively correlated (Table 3), while

316 the annual mean concentration of total $\mathrm{SO}_{2}$ only correlated with that of the $\mathrm{NO}_{2}$ derived from

317 shipping.

Table 2. Means \pm standard deviations (SDs) for tree characteristics and Pinus sylvestris bark and lichen variables in the Helsinki metropolitan area and Teijo and/or Pallas National Parks in summer 2016. $\mathrm{DBH}=$ diameter at breast height. Number of sites: Pallas $(\mathrm{n}=3)$, Teijo $(\mathrm{n}=$ 3 ) and Helsinki $(\mathrm{n}=38$, except Hypogymnia physodes chemistry $\mathrm{n}=34$, Platismatia glauca chemistry $\mathrm{n}=6$ and Pseudevernia furfuracea chemistry $\mathrm{n}=10$ ). Letters indicate differences between the study areas at $\mathrm{p}<0.05$ (Student's t-test or Mann-Whitney U-test).

\begin{tabular}{llll}
\hline & Pallas & Teijo & Helsinki \\
\hline Canopy cover $(\%)$ & $13 \pm 3 \mathrm{a}$ & $27 \pm 6 \mathrm{~b}$ & $30 \pm 14 \mathrm{~b}$ \\
Tree height $(\mathrm{m})$ & $15 \pm 5$ & $13 \pm 3$ & $18 \pm 6$ \\
DBH $(\mathrm{cm})$ & $29 \pm 3$ & $30 \pm 4$ & $30 \pm 4$
\end{tabular}

330 Bark

$331 \quad \mathrm{pH}$

\section{$3.29 \pm 0.05 \mathrm{a}$} $\mathrm{NO}_{2}{ }^{-}+\mathrm{NO}_{3}{ }^{-}-\mathrm{N}\left(\mu \mathrm{g} \mathrm{g}^{-1}\right)$

$168 \pm 19 \mathrm{a}$

$4.19 \pm 0.68 \mathrm{a}$ $12.0 \pm 2.7 \mathrm{a}$ $318 \pm 25 \mathrm{a}$

$3.48 \pm 0.06 \mathrm{~b}$
$123 \pm 9 \mathrm{~b}$
$2.15 \pm 0.32 \mathrm{~b}$
$15.5 \pm 2.6 \mathrm{a}$
$370 \pm 18 \mathrm{a}$

$3.38 \pm 0.14 \mathrm{ab}$ $155 \pm 39 \mathrm{ab}$ $6.30 \pm 6.05 \mathrm{a}$ $29.6 \pm 19.8 \mathrm{~b}$ $458 \pm 74 \mathrm{~b}$
H. physodes
$\mathrm{C}(\%)$
$\mathrm{N}(\%)$
$\mathrm{C}: \mathrm{N}$
$\delta^{15} \mathrm{~N}(\% o)$
$43.1 \pm 0.6 \mathrm{a}$
$44.7 \pm 0.2 b$
44. $1 \pm 0.6 \mathrm{~b}$
$0.77 \pm 0.14 \mathrm{a}$
$1.00 \pm 0.03 \mathrm{ab}$
$1.37 \pm 0.32 b$
$57.0 \pm 10.5 \mathrm{a}$
$44.8 \pm 1.2 \mathrm{a}$
$33.9 \pm 8.1 \mathrm{~b}$
$-5.07 \pm 0.34 \mathrm{a}$
$-6.45 \pm 0.14 b$
$-5.90 \pm 1.04 a b$
P. glauca
$\mathrm{C}(\%)$
$44.0 \pm 0.5$
$43.6 \pm 0.2$
$\mathrm{N}(\%)$
$0.97 \pm 0.07$
$1.16 \pm 0.34$
$\mathrm{C}: \mathrm{N}$
$45.6 \pm 3.1$
$40.1 \pm 10.1$
$\delta^{15} \mathrm{~N}(\% \circ)$
$-6.15 \pm 0.44$
$-5.50 \pm 0.50$
P. furfuracea
$\mathrm{C}(\%)$
$45.5 \pm 0.2$
$45.1 \pm 0.5$
$\mathrm{N}(\%)$
$\mathrm{C}: \mathrm{N}$
$1.32 \pm 0.04$
$1.55 \pm 0.32$
$34.4 \pm 0.9$
$30.2 \pm 6.3$
$\delta^{15} \mathrm{~N}(\% \circ)$
$-3.50 \pm 0.06 \mathrm{a}$

351

352 
Table 3. Spearman rank correlation or Pearson correlation coefficients for statistically significant relationships between selected bark chemistry and environmental variables in the Helsinki metropolitan area in summer $2016(\mathrm{n}=38)$. The asterisks indicate significances as follows: $* \mathrm{p} \leq$ $0.05, * * \mathrm{p} \leq 0.01, * * * \mathrm{p} \leq 0.001$.

\begin{tabular}{|c|c|c|c|c|c|c|c|c|c|c|}
\hline & $\begin{array}{l}\text { Canopy } \\
\text { cover } \\
(\%)\end{array}$ & $\begin{array}{l}\text { Total } \mathrm{NO}_{2} \\
\left(\mu \mathrm{g} \mathrm{m}^{-3} \mathrm{yr}^{-1}\right)\end{array}$ & $\begin{array}{l}\text { Road } \mathrm{NO}_{2} \\
\left(\mu \mathrm{g} \mathrm{m}^{-3} \mathrm{yr}^{-1}\right)\end{array}$ & $\begin{array}{l}\text { Shipping } \mathrm{NO}_{2} \\
\left(\mu \mathrm{g} \mathrm{m}^{-3} \mathrm{yr}^{-1}\right)\end{array}$ & $\begin{array}{l}\text { Total } \mathrm{SO}_{2} \\
\left(\mu \mathrm{g} \mathrm{m}^{-3} \mathrm{yr}^{-1}\right)\end{array}$ & $\begin{array}{l}\text { Total } \mathrm{PM}_{2.5} \\
\left(\mu \mathrm{g} \mathrm{m}^{-3} \mathrm{yr}^{-1}\right)\end{array}$ & $\frac{\text { Bark }}{\mathrm{pH}}$ & $\begin{array}{l}\text { Conductivity } \\
\qquad\left(\mu \mathrm{S} \mathrm{cm}^{-1}\right)\end{array}$ & $\begin{array}{c}\log \mathrm{NO}_{2}^{-}+\mathrm{NO}_{3}^{-}-\mathrm{N} \\
\left(\mu \mathrm{g} \mathrm{g}^{-1}\right)\end{array}$ & $\begin{array}{c}\log \mathrm{NH}_{4}{ }^{+}-\mathrm{N} \\
\left(\mu \mathrm{g} \mathrm{g}^{-1}\right)\end{array}$ \\
\hline $\begin{array}{l}\text { Distance }(\mathrm{km}) \text { from } \\
\text { city centre } \\
\text { sea }\end{array}$ & $-0.42 * *$ & $-0.65 * * *$ & $-0.49 * *$ & $-0.75 * * *$ & $\begin{array}{l}-0.59 * * * \\
-0.62 * * *\end{array}$ & $-0.48 * *$ & $0.62 * * *$ & $\begin{array}{l}-0.39 * * \\
-0.59 * * *\end{array}$ & $-0.47 * *$ & $\begin{array}{l}-0.57 * * * \\
-0.38 *\end{array}$ \\
\hline Canopy cover (\%) & & $0.48 * *$ & $0.44 * *$ & & & $0.50 * *$ & & & $0.43 * *$ & $0.37 *$ \\
\hline $\begin{array}{l}\text { Air quality } \\
\text { Total } \mathrm{NO}_{2}\left(\mu \mathrm{g} \mathrm{m}^{-3} \mathrm{yr}^{-1}\right) \\
\text { Road } \mathrm{NO}_{2}\left(\mu \mathrm{g} \mathrm{m}^{-3} \mathrm{yr}^{-1}\right) \\
\text { Energy } \mathrm{NO}_{2}\left(\mu \mathrm{g} \mathrm{m}^{-3} \mathrm{yr}^{-1}\right) \\
\text { Shipping } \mathrm{NO}_{2}\left(\mu \mathrm{g} \mathrm{m}^{-3} \mathrm{yr}^{-1}\right) \\
\text { Total } \mathrm{SO}_{2}\left(\mu \mathrm{g} \mathrm{m}^{-3} \mathrm{yr}^{-1}\right) \\
\text { Total } \mathrm{PM}_{2.5}\left(\mu \mathrm{g} \mathrm{m}^{-3} \mathrm{yr}^{-1}\right)\end{array}$ & & & $0.90 * * *$ & & $\begin{array}{l}0.92 * * * \\
0.92 * * * \\
0.53 * *\end{array}$ & $\begin{array}{l}0.36^{*} \\
0.38^{*}\end{array}$ & $\begin{array}{l}-0.56 * * * \\
-0.65 * * * \\
0.43 *\end{array}$ & $\begin{array}{l}0.39 * \\
0.80 * * *\end{array}$ & $0.35 *$ & $\begin{array}{l}0.51 * * \\
0.33 * \\
0.32 * \\
0.45^{* *} \\
0.43 * *\end{array}$ \\
\hline $\begin{array}{l}\text { Bark } \\
\text { pH } \\
\text { Conductivity }\left(\mu \mathrm{S} \mathrm{cm}^{-1}\right) \\
\log \mathrm{NO}_{2}^{-}+\mathrm{NO}_{3}^{-}-\mathrm{N}\left(\mu \mathrm{g} \mathrm{g}^{-1}\right) \\
\log \mathrm{S}\left(\mu \mathrm{g} \mathrm{g}^{-1}\right)\end{array}$ & $0.55 * * *$ & $0.51 * * *$ & $0.41 *$ & & $0.41 *$ & & & $-0.69 * * *$ & $\begin{array}{l}0.47 * * \\
0.37 * \\
\end{array}$ & $\begin{array}{l}0.50 * * * \\
0.65 * * * \\
0.58 * * \\
\end{array}$ \\
\hline
\end{tabular}




\subsection{Frequencies of lichen species}

At one site in the Helsinki metropolitan area, 10 out of 12 indicator species were recorded, i.e. all except $P$. sulcata and T. chlorophylla. Hypocenomyce scalaris was found and green algae $+S$. chlorococcum also grew at the three sites where there was no $H$. physodes. At those sites where $H$. physodes occurred, it was observed on most of the trunks, having an average frequency of 4 across the sites (Fig. 2). The frequency of $V$. pinastri increased as a function of an increasing frequency of green algae $+S$. chlorococcum, while the frequencies of $P$. ambigua, P. hyperopta \& I. aleurites, Usnea spp., P. glauca and P. furfuracea were negatively correlated with the latter (data not shown; all $\mathrm{p}<0.05$ ). In the Helsinki metropolitan area, Bryoria spp. and P. glauca were found at inland sites at a distance of $\geq 13$ $\mathrm{km}$ from the city centre and major point sources, and Usnea spp. and P. furfuracea at sites $\geq 11 \mathrm{~km}$ from the city centre. In Teijo, $P$. glauca and $P$. furfuracea were almost as frequent as H. physodes and P. ambigua (Figs 2 and 3).

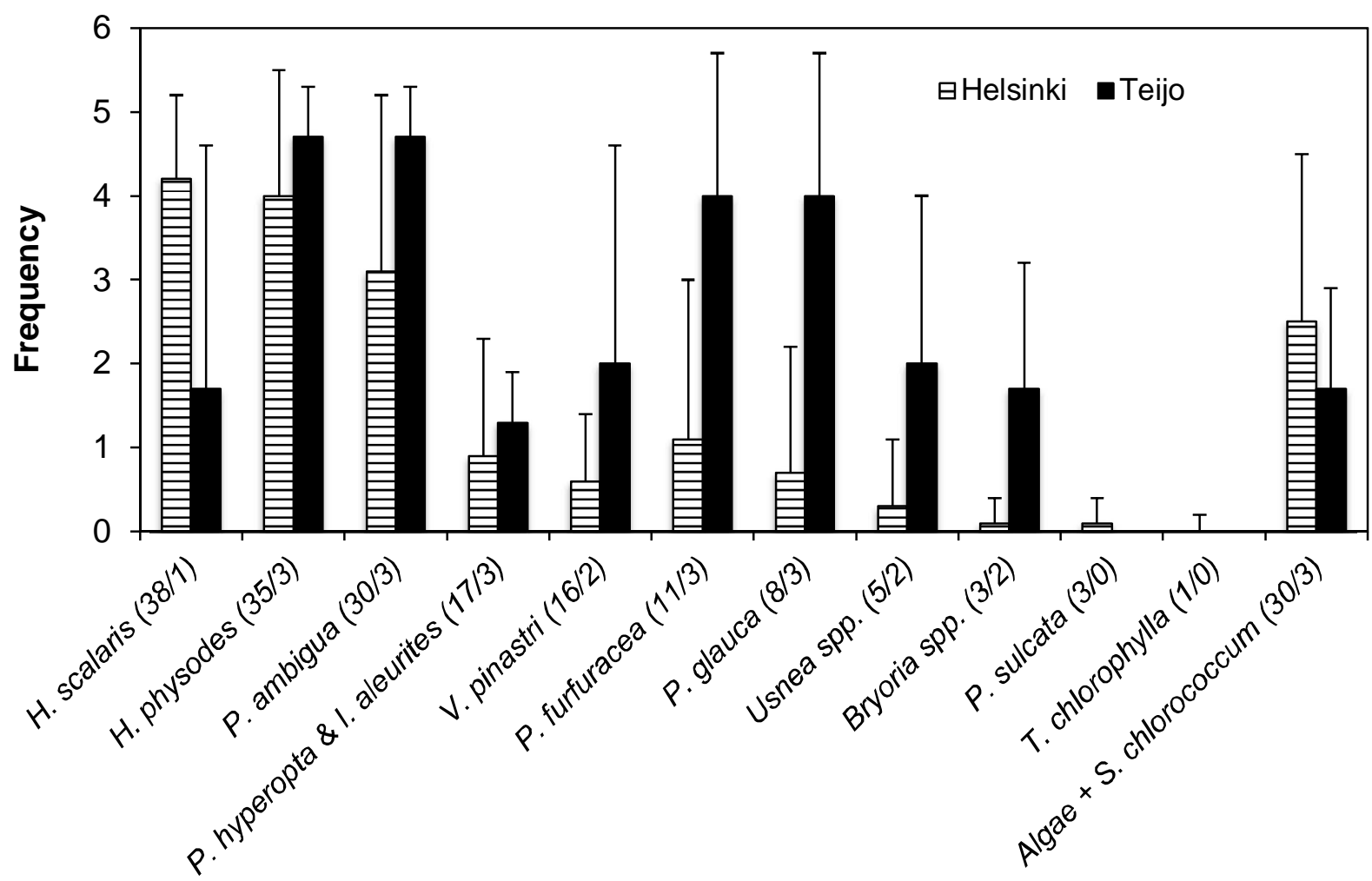

394 Fig. 2. Average frequencies ( \pm SD) of acidophytic indicator lichen species on Pinus sylvestris trunks across the sites in the Helsinki metropolitan area or Teijo National Park, southern Finland, in summer 2016. At each site, the frequency $(0=$ absent, $1=$ present $)$ of each species was scored on five trees, i.e. the maximum frequency of each species was 5 per site. The species are arranged from left to right according to the number of sites at which they grew in 
the Helsinki metropolitan area, except for the frequency of $\mathrm{N}$-loving green algae + Scoliciosporum chlorococcum which is shown on the far right. The number of sites where the species were found in the Helsinki metropolitan area / Teijo are given in parentheses. For instance, Pseudevernia furfuracea grew at 11 sites (out of 38) in the Helsinki metropolitan area, it grew at each of the three sites while in Teijo.

404

405

a)

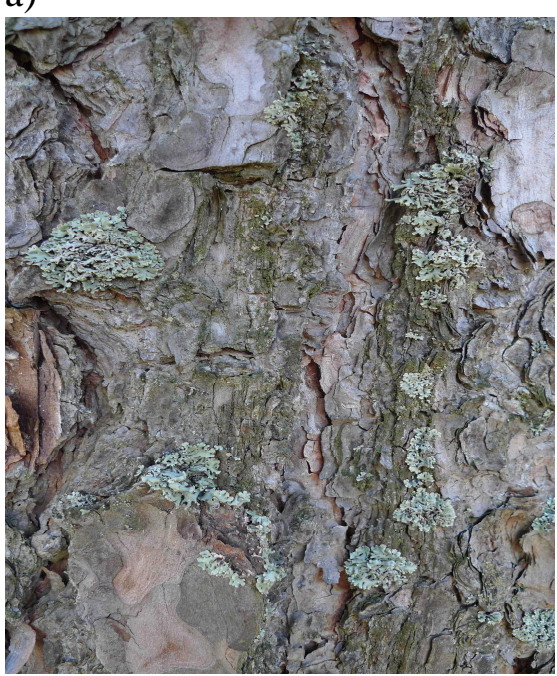

b)

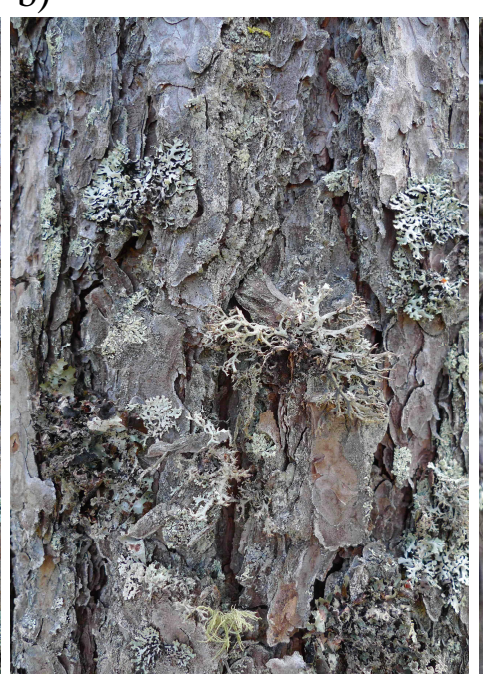

c)

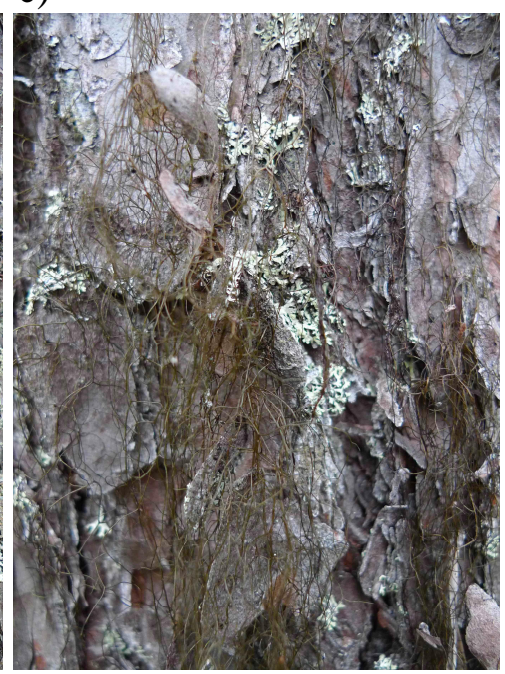

Fig. 3. Epiphytic lichens on Pinus sylvestris trunks at a) a polluted urban site in the Helsinki metropolitan area, and background sites in b) Teijo and c) Pallas National Parks in southern and northern Finland, respectively.

\section{3 $\mathrm{C}$ and $\mathrm{N}$ contents and $\delta^{15} \mathrm{~N}$ values of lichens}

413 The average $\mathrm{C}$ content of $H$. physodes was greater in southern Finland, i.e. both the Helsinki 414 metropolitan area and Teijo, than in Pallas. The $\mathrm{N}$ contents in $H$. physodes ranged from $0.92 \%$ to $2.04 \%$ in the Helsinki metropolitan area, with an average $\mathrm{N}$ content greater than that in 416 Pallas (Table 2). The highest $\mathrm{N}$ contents of $H$. physodes (approx. 2\%) were measured at two 417 sites: an island site within 300--800 m from a dual carriageway (52 000 cars per day), 418 Helsinki Zoo and the largest coal power plant, and at a park site approximately $100 \mathrm{~m}$ from a 419 four-lane street in the city centre (36 000 cars per day) (City of Helsinki; Finnish Transport 420 Agency). The elevated $\mathrm{N}$ contents resulted in a lower average $\mathrm{C}: \mathrm{N}$ ratio of $H$. physodes in the 421 Helsinki metropolitan area than in both Teijo and Pallas.

The $\delta^{15} \mathrm{~N}$ value of $H$. physodes tended to increase as a function of an increasing lichen $\mathrm{N}$ content in the Helsinki metropolitan area $(r=0.30, p=0.082)$ (Fig. 4a), while the $\mathrm{C}$ content of $H$. physodes was negatively correlated with its $\mathrm{N}$ content at $\mathrm{p}=0.1(\mathrm{r}=-0.286)$. The $\mathrm{N}$ 425 contents of $P$. glauca and $P$. furfuracea were positively correlated with that of $H$. physodes $(\mathrm{r}$ $426=0.90, \mathrm{p}=0.015$ and $\mathrm{r}=0.88, \mathrm{p}=0.001$, respectively) in the Helsinki metropolitan area, but 
the $\delta^{15} \mathrm{~N}$ values of the three species were not correlated (data not shown). Moreover, when $H$. physodes, $P$. glauca and/or $P$. furfuracea occurred at the same sites, the highest $\mathrm{N}$ content was recorded in $P$. furfuracea. In the Helsinki metropolitan area, the difference was significant in comparison to $H$. physodes $(\mathrm{t}=2.26, \mathrm{p}=0.038)$, and in Teijo also in comparison to $P$. glauca $\left(\mathrm{t}=11.88, \mathrm{p}<0.001\right.$ and $\mathrm{t}=7.87, \mathrm{p}=0.001$, respectively). The average $\delta^{15} \mathrm{~N}$ value of $P$. furfuracea in Teijo was greater than that of $H$. physodes or $P$. glauca $(\mathrm{t}=34.1, \mathrm{p}<0.001$ or $\mathrm{t}$ $=10.3, \mathrm{p}=0.008$, respectively), and it was also greater than that of $P$. furfuracea in the Helsinki metropolitan area (Table 2).

435

a)

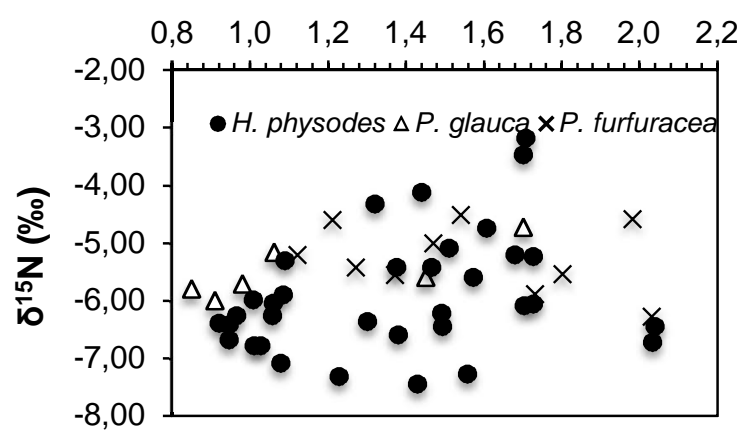

b)

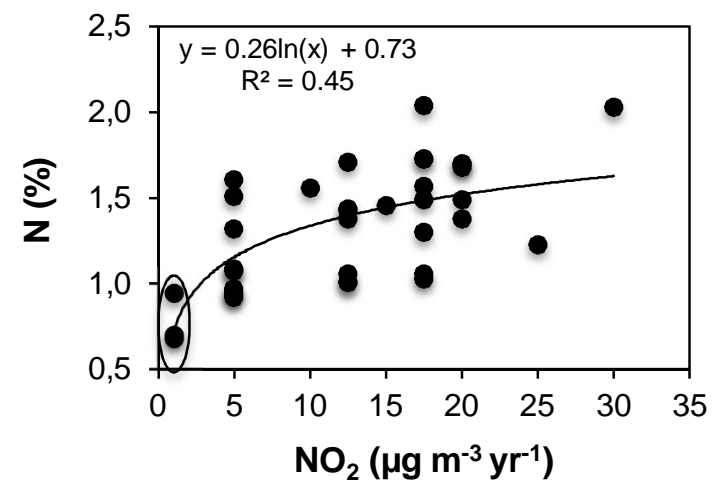

\subsection{Relationships between lichen species and environmental variables}

444 The total and average numbers of indicator lichen species decreased as a function of increasing atmospheric concentrations of total $\mathrm{NO}_{2}$ and total $\mathrm{SO}_{2}$, as well as increasing concentrations of inorganic $\mathrm{N}$ fractions and $\mathrm{S}$ in bark. Hypocenomyce scalaris, V. pinastri and green algae $+S$. chlorococcum appeared to be the most tolerant species in terms of $\mathrm{N}$ deposition (Table 4). Hypogymnia physodes decreased in frequency as a function of increasing concentrations of both atmospheric total $\mathrm{NO}_{2}$ and bark $\mathrm{NO}_{2}{ }^{-}+\mathrm{NO}_{3}{ }^{-}-\mathrm{N}$. While the frequencies of $P$. ambigua and $P$. furfuracea responded negatively to both the $\mathrm{NO}_{2}^{-}+\mathrm{NO}_{3}{ }^{-}-\mathrm{N}$ and $\mathrm{NH}_{4}{ }^{+}-\mathrm{N}$ concentrations in bark, the frequencies of Bryoria spp. and Usnea spp. were negatively and solely correlated with the bark $\mathrm{NO}_{2}{ }^{-}+\mathrm{NO}_{3}-\mathrm{N}$ concentration, and the frequency of $P$. glauca with the bark $\mathrm{NH}_{4}{ }^{+}-\mathrm{N}$ concentration. The frequencies of $P$. ambigua and $P$. 
454 glauca were also negatively correlated with the atmospheric total $\mathrm{SO}_{2}$ concentration, as was 455 the frequency of $V$. pinastri. Vulpicida pinastri was the only species that responded to changes in bark $\mathrm{pH}$, i.e. its frequency increased as a function of increasing bark $\mathrm{pH}$, while $P$. ambigua, P. hyperopta \& I. aleurites and P. glauca responded negatively to an increase in the bark S concentration (Table 4). The frequency of green algae $+S$. chlorococcum, in turn, tended to be positively correlated with the bark $S$ concentration $\left(r_{S}=0.32, p=0.053\right)$.

The $\mathrm{N}$ content of $H$. physodes was positively correlated with the bark $\mathrm{NH}_{4}{ }^{+}-\mathrm{N}$ concentrations (Table 4), but it also tended to increase with an increasing atmospheric total $\mathrm{NO}_{2}$ concentration and bark $\mathrm{NO}_{2}{ }^{-}+\mathrm{NO}_{3}{ }^{-} \mathrm{N}$ concentration $\left(\mathrm{r}_{\mathrm{S}}=0.32, \mathrm{p}=0.065\right.$ and $\mathrm{r}=0.34, \mathrm{p}$ $=0.051$, respectively). When data from the Helsinki metropolitan area and Pallas were combined, the atmospheric total $\mathrm{NO}_{2}$ concentration explained $45 \%$ of the variation in the $\mathrm{N}$ content of $H$. physodes (Fig. 4b). Although the $\mathrm{C}$ content of $H$. physodes only decreased significantly as a function of increasing bark $\mathrm{pH}$, it also showed negative correlations with the atmospheric total $\mathrm{NO}_{2}$ and total $\mathrm{PM}_{2.5}$ concentrations at $\mathrm{p}<0.1$. The $\mathrm{N}$ content of $P$. furfuracea decreased with increasing distance from the city centre $(r=-0.74, p=0.014)$, as did that of $H$. physodes, while that of $P$. glauca only tended to weakly to decrease $(\mathrm{r}=-0.78, \mathrm{p}$ $=0.067)$. The $\mathrm{N}$ content of $P$. furfuracea actually increased with an increasing $\mathrm{NO}_{2}$ concentration derived from shipping ( $\mathrm{r}_{\mathrm{S}}=0.64, \mathrm{p}=0.046$ ), and the $\delta^{15} \mathrm{~N}$ value of $P$. glauca increased with an increasing $\mathrm{NO}_{2}$ concentration derived from energy production $\left(\mathrm{r}_{\mathrm{S}}=0.88, \mathrm{p}\right.$ $473=0.021)$.

PCA of air quality and selected lichen and bark variables from the Helsinki metropolitan area resulted in five principal components (PCs) with initial eigenvalues of $>1$. These PCs explained $74 \%$ of the variation in the data. A biplot from the PCA is presented in Fig. 5. PC1 was named the ' $\mathrm{N}$ pollution' gradient. The annual mean total $\mathrm{NO}_{2}$ and road traffic-derived $\mathrm{NO}_{2}$ concentrations, total $\mathrm{PM}_{2.5}$ concentration, the $\mathrm{N}$ content of $H$. physodes, bark $\mathrm{S}$ concentration and the frequency of green algae $+S$. chlorococcum were positively loaded (>0.50), while the $\mathrm{C}$ content of $H$. physodes was negatively loaded on PC1. The annual mean total $\mathrm{SO}_{2}$ concentration, $\mathrm{NO}_{2}$ concentration derived from shipping, bark $\mathrm{N}$ fractions and conductivity were, in turn, positively loaded on PC2, in contrast to the bark $\mathrm{pH}$. The average number of indicator lichen species was equally strongly negatively loaded on both PC1 and 
Table 4. Spearman rank correlation or Pearson correlation coefficients for statistically significant relationships between lichen variables and environmental factors in the Helsinki metropolitan area in summer $2016(\mathrm{n}=38$, except for Hypogymnia chemistry $\mathrm{n}=34)$. The asterisks indicate significances as follows: $* \mathrm{p} \leq 0.05, * * \mathrm{p} \leq 0.01, * * * \mathrm{p} \leq 0.001$

\begin{tabular}{|c|c|c|c|c|c|c|c|c|c|c|}
\hline & $\begin{array}{l}\text { Distance from } \\
\text { city centre } \\
(\mathrm{km})\end{array}$ & $\begin{array}{l}\text { Total } \mathrm{NO}_{2} \\
\left(\mu \mathrm{g} \mathrm{m}^{-3} \mathrm{yr}^{-1}\right)\end{array}$ & $\begin{array}{l}\text { Road } \mathrm{NO}_{2} \\
\left(\mu \mathrm{g} \mathrm{m}^{-3} \mathrm{yr}^{-1}\right)\end{array}$ & $\begin{array}{l}\text { Total } \mathrm{SO}_{2} \\
\left(\mu \mathrm{g} \mathrm{m}^{-3} \mathrm{yr}^{-1}\right)\end{array}$ & $\begin{array}{l}\text { Total } \mathrm{PM}_{2.5} \\
\left(\mu \mathrm{g} \mathrm{m}^{-3} \mathrm{yr}^{-1}\right)\end{array}$ & $\frac{\text { Bark }}{\mathrm{pH}}$ & $\begin{array}{l}\text { conductivity } \\
\left(\mu \mathrm{S} \mathrm{cm}^{-1}\right)\end{array}$ & $\begin{array}{l}\log \mathrm{NO}_{2}{ }^{-}+\mathrm{NO}_{3}{ }^{-}-\mathrm{N} \\
\left(\mu \mathrm{g} \mathrm{g}^{-1}\right)\end{array}$ & $\begin{array}{l}\log \mathrm{NH}_{4}{ }^{-}-\mathrm{N} \\
\left(\mu \mathrm{g} \mathrm{g}^{-1}\right)\end{array}$ & $\begin{array}{l}\log \mathrm{S} \\
\left(\mu \mathrm{g} \mathrm{g}^{-1}\right)\end{array}$ \\
\hline $\begin{array}{l}\text { Total number of } \\
\text { indicator species }\end{array}$ & $0.60 * * *$ & $-0.36^{*}$ & & $-0.41 * *$ & & & $-0.40 *$ & $-0.45 * *$ & $-0.45 * *$ & $-0.43 * *$ \\
\hline $\begin{array}{l}\text { Average number } \\
\text { of indicator species }\end{array}$ & $0.54 * * *$ & $-0.44 *$ & $-0.32 *$ & $-0.37 *$ & & & $-0.40 * *$ & $-0.63 * * *$ & $-0.53 * *$ & $-0.40 *$ \\
\hline \multicolumn{11}{|l|}{ Frequency } \\
\hline H. physodes & $0.42 * *$ & $-0.41 *$ & & & & & & $-0.35^{*}$ & & \\
\hline $\begin{array}{l}\text { P. ambigua } \\
\text { P. hyperopta \& }\end{array}$ & $0.59 * * *$ & $-0.50 * *$ & $-0.38 *$ & $-0.45 * *$ & $-0.44 * *$ & & $-0.42 * *$ & $-0.47 * *$ & $-0.67 * * *$ & $-0.53 * * *$ \\
\hline I. alurites & $0.32 *$ & $-0.37 *$ & & & & & & & & $-0.54 * * *$ \\
\hline $\begin{array}{l}\text { H. scalaris } \\
\text { Bryoria } \mathrm{spp} .\end{array}$ & & & & & & & $0.34 *$ & $-0.33^{*}$ & & \\
\hline Usnea spp. & $0.46^{* *}$ & $-0.41 *$ & & & & & & $-0.36^{*}$ & & \\
\hline $\begin{array}{l}P . \text { glauca } \\
V . \text { pinastri }\end{array}$ & $0.60 * * *$ & $\begin{array}{c}-0.40^{*} \\
0.35^{*}\end{array}$ & & $\begin{array}{l}-0.35^{*} \\
-0.33^{*}\end{array}$ & $\begin{array}{c}-0.36^{*} \\
0.36^{*}\end{array}$ & $0.48 * *$ & $-0.55 * * *$ & & $-0.49 * *$ & $-0.37 *$ \\
\hline P. furfuracea & $0.46^{* *}$ & $-0.59 * * *$ & $-0.46^{* *}$ & & $-0.51 * *$ & & & $-0.40 *$ & $-0.45 * *$ & \\
\hline $\begin{array}{l}\text { Green algae }+ \\
\quad \text { S. chlorococcum }\end{array}$ & $-0.41 * *$ & $0.57 * * *$ & $0.45 * *$ & & $0.52 * *$ & & & & $0.36^{*}$ & \\
\hline \multicolumn{11}{|l|}{ H. physodes } \\
\hline $\log N(\%)$ & $-0.45 * *$ & & & & $0.48 * *$ & & & & $0.56 * * *$ & $0.58 * * *$ \\
\hline $\log C(\%)$ & & & & & & $-0.34^{*}$ & & & & \\
\hline $\mathrm{C}: \mathrm{N}$ & $0.37 *$ & $-0.55 * * *$ & & & $-0.52 * *$ & & & & $-0.56 * * *$ & $-0.59 * * *$ \\
\hline
\end{tabular}




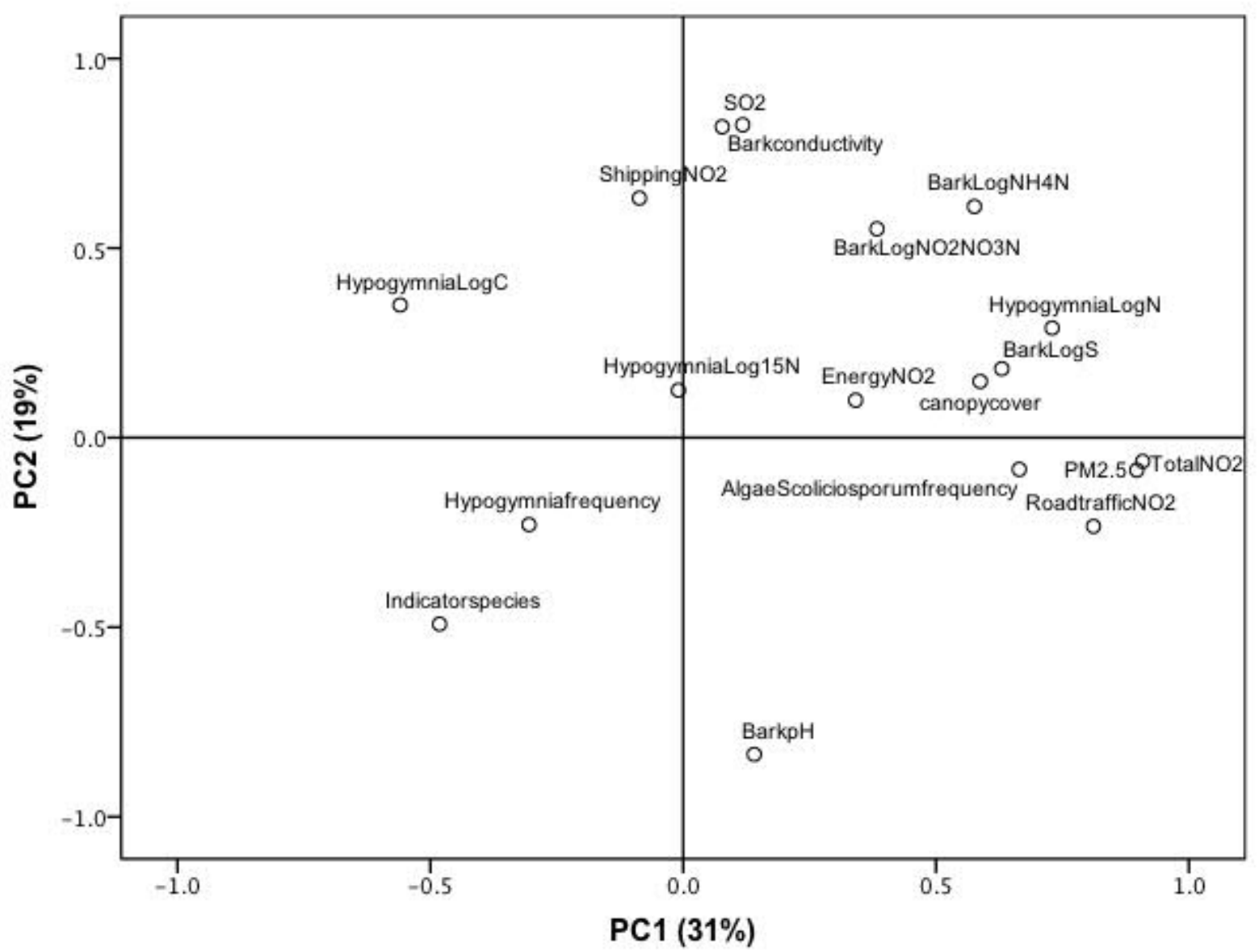

519 Fig. 5. Biplot from the principal component analysis (PCA) of the average number of 520 indicator lichen species, frequencies of Hypogymnia physodes and green algae + 521 Scoliciosporum chlorococcum, $H$. physodes chemistry and environmental drivers (canopy cover, annual means for total concentrations of $\mathrm{NO}_{2}, \mathrm{SO}_{2}$ and $\mathrm{PM}_{2.5}$, as well as $\mathrm{NO}_{2}$ concentrations derived from various sources, and selected bark chemistry variables) in the Helsinki metropolitan area in summer 2016. PC1 explained 31\% and PC2 19\% of the variation in the data.

\section{4. Discussion}

\subsection{Effects of nitrogen pollution on the epiphytic lichen community}

530 The fact that the frequencies of $P$. glauca and $P$. furfuracea were positively and the frequency

531 of green algae $+S$. chlorococcum negatively correlated with distance from the city centre, but

532 that none of these frequencies correlated with the canopy cover or DBH, provides support for

533 the hypothesis that urban air pollution has a major impact on the acidophytic lichen

534 communities on P. sylvestris trunks in the Helsinki metropolitan area. The relationships

535 between the frequencies of indicator lichen species, lichen $\mathrm{N}$ contents or $\delta^{15} \mathrm{~N}$ values and 536 atmospheric $\mathrm{NO}_{2}$ and $\mathrm{PM}_{2.5}$ concentrations, as well as the concentrations of $\mathrm{NO}_{2}{ }^{-}+\mathrm{NO}_{3}{ }^{-} \mathrm{N}$ and 
$\mathrm{NH}_{4}{ }^{+}-\mathrm{N}$ in $P$. sylvestris bark provide further support for the negative effects of reactive $\mathrm{N}$ compounds derived mainly from road traffic on epiphytic lichens. The results indicate species-specific responses to $\mathrm{N}$ forms, however, and some species may have responded to the total $\mathrm{N}$ flux rather than to the concentration (Mitchell et al., 2005; Munzi et al., 2010).

Van Herk (1999) classified both H. physodes and P. furfuracea as acidophytes sensitive to $\mathrm{NH}_{3}$ as well as the $\mathrm{NH}_{4}{ }^{+}$concentration of bark, although $H$. physodes has generally been considered as an N-tolerant species (Dahlman et al., 2003; Mitchell et al., 2005). Based on the present results, $P$. furfuracea, $P$. ambigua and $P$. glauca, in particular, responded negatively to an increased bark $\mathrm{NH}_{4}{ }^{+}$concentration, while green algae $+S$. chlorococcum benefited from the eutrophication of $P$. sylvestris bark. A significant impact of oxidized $\mathrm{N}$ compounds (Dahlman et al., 2004) was also found in the Helsinki metropolitan area in terms of the strong negative correlation between the frequency of $P$. furfuracea and atmospheric total $\mathrm{NO}_{2}$ concentration and the negative correlations between bark $\mathrm{NO}_{2}{ }^{-}+\mathrm{NO}_{3}{ }^{-}-\mathrm{N}$ concentration and the frequencies of Bryoria spp., Usnea spp. and P. furfuracea. The $\mathrm{NO}_{3}{ }^{-}$sensitivity of fruticose acidophytic lichens is attributed to their low constitutive nitrate reductase activity (Gombert et al., 2003 and references therein).

553

\subsection{Effects of nitrogen pollution on lichen chemistry}

The average $\mathrm{N}$ contents of $H$. physodes and $P$. glauca have varied from $0.3 \%$ to $0.6 \%$ (Bruteig, 1993; Dahlman et al., 2003; Geiser and Neitlich, 2007; Geiser et al., 2010; Green et al., 1980; Johansson et al., 2010, 2011; Søchting, 1995) in background areas such as those receiving 0.5--2.0 $\mathrm{kg} \mathrm{N}$ ha $^{-1} \mathrm{yr}^{-1}$ (Dahlman et al., 2003; Johansson et al., 2010, 2011) or 0.02-$0.1 \mathrm{mg} \mathrm{NH}_{4}{ }^{+}-\mathrm{N}^{-1}$ in precipitation (Bruteig, 1993; Geiser and Neitlich, 2007). In the Helsinki metropolitan area, the highest $\mathrm{N}$ content of $H$. physodes was only twice the lowest content. It was, however, greater than $1.0--1.5 \%$ in $H$. physodes that had been exposed to $50--100 \mathrm{~kg}$ $\mathrm{NH}_{4} \mathrm{NO}_{3}-\mathrm{N} \mathrm{ha}^{-1} \mathrm{yr}^{-1}$ in an irrigation-fertilization experiment in Sweden (Dahlman et al., 2003). The highest $\mathrm{N}$ content of $P$. glauca (1.70\%) was in turn as high as in the Swedish irrigation experiments (Dahlman et al., 2003; Johansson et al., 2010, 2011, 2012), although the total N deposition in the Helsinki metropolitan area is expected to be lower than in those experiments. The apparently high 'precipitation' explains why the lichen $\mathrm{N}$ contents (on P. abies branches) were relatively low in the high $\mathrm{NH}_{4} \mathrm{NO}_{3}$ irrigation-fertilization treatments (Bruteig, 1993; Geiser et al., 2010).

The isotopic composition of rainfall changes when it filters through the P. sylvestris 
wet-deposited N-containing gases, aerosol particles and pH (Heaton et al., 1997). Given this, the scatter seen in Fig. 2a may be considered typical for areas with both large point sources and line sources and where the emissions and concentrations of different $\mathrm{N}$ forms vary within small spatial scales. Despite the wide variation, the $\delta^{15} \mathrm{~N}$ values of $H$. physodes and $P$. glauca suggest an increasing contribution of oxidized N (Ammann et al., 1999; Pearson et al., 2000), with an increasing $\mathrm{N}$ content of lichen thalli in the Helsinki metropolitan area. Thus, the $\delta^{15} \mathrm{~N}$ values support the important role of $\mathrm{NO}_{3}{ }^{-}$in terms of $\mathrm{N}$ uptake by epiphytic lichens and the composition of the acidophytic lichen community, including the frequency of $H$. physodes (Hauck and Runge, 2002; Hauck et al., 2002; Lang et al., 1976; Larsen et al., 2007; Schmull et al., 2002). Some studies have actually suggested that at ecologically relevant $\mathrm{N}$ concentrations and doses, there is no difference in the uptake of dissolved $\mathrm{NO}_{3}{ }^{-}$and $\mathrm{NH}_{4}{ }^{+}$ throughout the lichen thallus, especially in boreal and Antarctic lichens (Crittenden, 1998; Johansson et al., 2010). Moreover, the $\mathrm{N}$ contents of $P$. furfuracea indicated a higher uptake rate of $\mathrm{N}$ by the fruticose species than by the foliose $H$. physodes and $P$. glauca. This was attributed to a high uptake of oxidized N compounds (Dahlman et al., 2004; Lang et al., 1976) given the high average $\delta^{15} \mathrm{~N}$ value of $P$. furfuracea in the background area in Teijo.

The $\mathrm{N}$ content of $H$. physodes was also elevated in Pallas, where the $\mathrm{NH}_{4}{ }^{+}-\mathrm{N}$ concentration in precipitation was approximately $0.06 \mathrm{mg} \mathrm{l}^{-1}$ and that of $\mathrm{NO}_{3}{ }^{-}-\mathrm{N}$ approximately $0.13 \mathrm{mg} \mathrm{l}^{-1}$ (Ruoho-Airola et al., 2015). This was attributed to the overall increase in $\mathrm{NO}_{3}{ }^{-}$deposition since the late 1990s (Ruoho-Airola et al., 2015) and the relatively high precipitation in summer 2016, which dissolved the dry-deposited $\mathrm{N}$ on the lichen surfaces (Gombert et al., 2003; Lang et al., 1976). Bruteig (1993) reported that the lichen $\mathrm{N}$ content was particularly affected by wet $\mathrm{NO}_{3}{ }^{-}$deposition in the background areas, because the uptake rate was relatively more efficient at low deposition concentrations and at high altitudes, as in the north, where lichen growth is low (see also Levia, 2002). Moreover, Dahlman et al. (2004) demonstrated that $\mathrm{NO}_{3}{ }^{-}$uptake was, to a higher extent, active relative to that of $\mathrm{NH}_{4}{ }^{+}$. Notably, an $\mathrm{N}$ content of $0.97 \%$ was measured in Bryoria spp. in Pallas (Sirkku Manninen, unpublished).

The strong positive correlation between the $\mathrm{N}$ content of $H$. physodes and bark $\mathrm{NH}_{4}{ }^{+}-\mathrm{N}$ concentration was not surprising given the high passive uptake rate of $\mathrm{NH}_{4}{ }^{+}$by green algal 601 lichens (Dahlman et al., 2004; Lang et al., 1976; Palmqvist and Dahlman, 2006) and the 3--7602 fold average $\mathrm{NH}_{4}{ }^{+}-\mathrm{N}$ concentrations versus the $\mathrm{NO}_{2}{ }^{-}+\mathrm{NO}_{3}{ }^{-} \mathrm{N}$ concentrations of $P$. sylvestris 603 bark in the study areas. The latter is partly attributed to the predominance of $\mathrm{NH}_{4}{ }^{+}$in boreal 
604 forest soils (Bobbink et al., 2010; Högberg et al., 2006), given that soil affects the chemical composition of bark (Gauslaa, 1995; Gustafsson and Eriksson, 1995; Krouse, 1977).

The negative association between the $\mathrm{N}$ and $\mathrm{C}$ contents of $H$. physodes indicated an impact of elevated atmospheric concentrations and the deposition of reactive $\mathrm{N}$ compounds on $\mathrm{C}$ assimilation in lichens in the Helsinki metropolitan area. Since there is a seemingly tight regulation of resource investments and metabolic pathways between the symbionts in green algal foliose lichens (Palmqvist and Dahlman, 2006), the low C:N ratios of $H$. physodes thalli in the Helsinki metropolitan area as compared to those in Teijo and Pallas suggested disturbance in $\mathrm{C}$ to $\mathrm{N}$ stoichiometry between the symbiont partners (Palmqvist, 2000). The Nrelated decrease in $\mathrm{C}$ assimilation and the use of $\mathrm{C}$ to reduce $\mathrm{NO}_{3}{ }^{-}$to $\mathrm{NH}_{4}{ }^{+}$, as well as to detoxify $\mathrm{NH}_{4}{ }^{+}$, results in reduced growth of thalli (Dahlman et al., 2002; Gaio-Oliveira et al., 2005; Johansson et al., 2011), as observed in the Helsinki metropolitan area.

\subsection{Role of $\mathrm{SO}_{2}$ and other environmental factors}

618 Although the ambient $\mathrm{SO}_{2}$ and $\mathrm{SO}_{4}{ }^{2-}-\mathrm{S}$ aerosol concentrations are currently low in the Helsinki metropolitan area (Hannuniemi et al., 2016; Kaski et al., 2016; Teinilä et al., 2016), the direct deposition of $\mathrm{SO}_{2}$ and aerosols on lichen surfaces, $\mathrm{SO}_{4}-\mathrm{S}$ in rainwater, and particulate $\mathrm{SO}_{4}{ }^{2-}-\mathrm{S}$ deposited on bark (Krouse, 1977) still negatively affect the composition of the acidophytic lichen community. The results thus suggest a need for revision of the CLE for $\mathrm{SO}_{2}$ and/or CLO for $\mathrm{S}$ deposition. In fact, the increase in the frequency of green algae $+S$. chlorococcum towards the city centre may also partly be explained by the positive effect of an elevated concentration of $\mathrm{S}$ in the bark on the algal cover (Grandin, 2011). Notably, the $\mathrm{SO}_{2}-$ tolerant L. conizaeoides, which was not included in the list of indicator species, was found at six sites in the Helsinki metropolitan area. An impact of windblown marine $\mathrm{SO}_{4}{ }^{2-}$ compounds and salts on bark chemistry cannot be excluded at some sites, but it was probably minor (Bates and Brown, 1981).

Snow-tolerant species such as $P$. ambigua, $P$. hyperopta and $V$. pinastri (i.e. Cetraria pinastri) may be mostly confined to the bases of conifers (Thell and Moberg, 2011), especially in polluted areas (Ahti, 1977). This was also observed in the present study especially in the case of $V$. pinastri, which appeared to be a relatively $\mathrm{N}$-tolerant species. Moreover, it was the only species that clearly responded to the bark $\mathrm{pH}$. Given this and the observed relationships between the frequencies of lichen species and atmospheric and/or bark chemistry, the changes in the lichen community on $P$. sylvestris trunks in the Helsinki metropolitan area can be attributed to the physiological responses of individual species to $\mathrm{N}$ 
and/or S deposition, rather than to changes in competitive interactions as a result of changes in the bark pH (see e.g. Johansson et al., 2012; van Herk, 1999).

\subsection{Nitrogen critical levels and loads}

642 Single small individuals of Bryoria spp. and/or Usnea spp. (mainly U. hirta) were found at sites with atmospheric total $\mathrm{NO}_{2}$ concentrations of $\leq 5 \mu \mathrm{g} \mathrm{m}^{-3} \mathrm{yr}^{-1}$, except on an island (12.5 $\left.\mu \mathrm{g} \mathrm{NO}_{2} \mathrm{~m}^{-3} \mathrm{yr}^{-1}\right)$ and at an inland site $\left(15 \mu \mathrm{g} \mathrm{NO}_{2} \mathrm{~m}^{-3} \mathrm{yr}^{-1}\right)$ in the Helsinki metropolitan area. These results and the elevated $\mathrm{N}$ contents in the lichen thalli indicate that the CLE of $30 \mu \mathrm{g} \mathrm{m}^{-}$ ${ }^{3} \mathrm{yr}^{-1}$ (CLTRAP, 2017) does not protect the acidophytic green algal lichens on conifer trunks, at least not when simultaneously occurring with even slightly elevated levels of $\mathrm{NH}_{3}$ and/or $\mathrm{SO}_{2}$, and N- or S-containing aerosols (van Herk, 2004). Geiser and Neitlich (2007) attributed the increasing abundance of nitrophytes and the absence of sensitive species to mean wet deposition of $>0.06 \mathrm{mg} \mathrm{NH}_{4}{ }^{+} 1^{-1}$ and a lichen $\mathrm{N}$ content of $>0.6 \%$, e.g. in P. glauca. While Geiser and Neitlich (2007) were not able to assess the potential role of the high $\mathrm{NO}_{\mathrm{x}}$ concentrations typical for the US Pacific Northwest or that of $\mathrm{SO}_{2}$, Bermejo-Orduna et al. (2014) recorded a strong negative association between the $\mathrm{N}$ content and cover of the acidophyte Letharia vulpina, with thallus $\mathrm{N}$ contents of $<1.0 \%$, in the vicinity of a transcontinental highway in the Sierra Nevada Mountains of California. If $1.0 \% \mathrm{~N}$ in $H$. physodes or $P$. glauca was set as a threshold, the CLE of $\mathrm{NO}_{2}$ would be $\leq 5 \mu \mathrm{g} \mathrm{m}^{-3} \mathrm{yr}^{-1}$, but if the CLE were set based on the N content of P. furfuracea, it would be even lower.

No data are available on $\mathrm{NH}_{3}$ concentrations or $\mathrm{PM}_{2.5}$ chemistry in the Helsinki metropolitan area, but an average $\mathrm{NH}_{4}{ }^{+}$concentration of $0.5 \mu \mathrm{g} \mathrm{m}^{-3}$, with 1-hr peaks of up to $2.2 \mu \mathrm{g} \mathrm{m}^{-3}$, was measured in $\mathrm{PM}_{1}$ in the city centre between 1 May 2013 and 30 April 2015. The means for $\mathrm{NO}_{3}{ }^{-}$and $\mathrm{SO}_{4}{ }^{2-}$ in $\mathrm{PM}_{1}$ were $0.7 \mu \mathrm{g} \mathrm{m}^{-3}$ and $0.9 \mu \mathrm{g} \mathrm{m}^{-3}$, respectively, with 1-hr peak concentrations of $6.6 \mu \mathrm{g} \mathrm{NO}_{3}{ }^{-} \mathrm{m}^{-3}$ and $2.4 \mu \mathrm{g} \mathrm{SO}_{4}{ }^{2-} \mathrm{m}^{-3}$ (Teinilä et al., 2016). Using a formula provided by Cape et al. (2004), $\mathrm{NH}_{3}$ concentrations of up to $10--12 \mu \mathrm{g} \mathrm{m}^{-3} \mathrm{yr}^{-1}$ were calculated at the edges of traffic lanes with the highest numbers of cars per day (City of Helsinki; Finnish Transport Agency). According to van Herk (2001), H. physodes appears to be absent at mean annual concentrations of $>13 \mu \mathrm{g} \mathrm{NH}_{3} \mathrm{~m}^{-3}$. Pinho et al. (2014) proposed a new CLE of $0.69 \mu \mathrm{g} \mathrm{NH}_{3} \mathrm{~m}^{-3} \mathrm{yr}^{-1}$ for Mediterranean evergreen woodlands, based on lichen diversity. Given the low levels of precipitation in both southern and northern Finland, a CLE of $<1 \mu \mathrm{g} \mathrm{NH}_{3} \mathrm{~m}^{-3} \mathrm{yr}^{-1}$ and a CLE of $\approx 0.5 \mu \mathrm{g} \mathrm{m}^{-3} \mathrm{yr}^{-1}$ of $\mathrm{N}$ in ambient-air fine particulates

670 (Geiser et al., 2010) are proposed for the protection of acidophytic lichens on conifer trunks in

671 boreal forests. Lower CLEs for gaseous and particulate $\mathrm{N}$ pollutants are also supported by the 
672 fact that elevated levels of these occur at the same time as elevated levels of $\mathrm{SO}_{2}$ and $\mathrm{SO}_{4}{ }^{2-}$ in 673 urban areas.

674 In the USA, the use of passive ion exchange resin-filled collectors (IER) to monitor 675 dissolved inorganic $\mathrm{N}$ (DIN) in throughfall has been shown to provide total DIN, $\mathrm{NO}_{3}{ }^{-} \mathrm{N}$ and $676 \mathrm{NH}_{4}{ }^{+}-\mathrm{N}$ rates that correlate well with changes in epiphytic communities and lichen $\mathrm{N}$ contents 677 (Fenn et al., 2008; Jovan et al., 2012; McMurray et al., 2013; Root et al., 2013). Based on the 678 regression between the $\mathrm{N}$ contents of $P$. glauca and $H$. physodes, the $\mathrm{N}$ content of $P$. glauca 679 was calculated for the most polluted sites at which the species did not grow in the Helsinki 680 metropolitan area. The results were further used to predict throughfall rates of total DIN, $\mathrm{NO}_{3}{ }^{-}$ $681-\mathrm{N}$ and $\mathrm{NH}_{4}{ }^{+}-\mathrm{N}$ based on the regressions of Root et al. (2013). The calculations yielded 682 throughfall rates of 2.1--25 $\mathrm{kg}$ total DIN ha ${ }^{-1} \mathrm{yr}^{-1}, 0.5--19 \mathrm{~kg} \mathrm{NO}_{3}^{-}-\mathrm{N} \mathrm{ha}^{-1} \mathrm{yr}^{-1}$ and $0.8--8.1 \mathrm{~kg}$ $683 \mathrm{NH}_{4}{ }^{+}-\mathrm{N} \mathrm{ha}^{-1} \mathrm{yr}^{-1}$ in the Helsinki metropolitan area. The average total DIN deposition 684 calculated for the sites in Teijo and Pallas were 3 and $1.5 \mathrm{~kg} \mathrm{ha}^{-1} \mathrm{yr}^{-1}$, respectively. The latter 685 is equal to the bulk deposition of $\mathrm{NO}_{3}{ }^{-}-\mathrm{N}+\mathrm{NH}_{4}{ }^{+}-\mathrm{N}$ in Pallas (Ruoho-Airola et al., 2015).

The European CLO of 5--10 $\mathrm{kg} \mathrm{N} \mathrm{ha}^{-1} \mathrm{yr}^{-1}$ proposed for pine taiga woodland is based on an increase in the occurrence of free-living algae (Bobbink and Hettelingh, 2011; see also Poikolainen et al., 1998). In the USA, McMurray et al. (2013) observed stunted growth of lichen thalli subjected to $4 \mathrm{~kg} \mathrm{~N} \mathrm{ha}^{-1} \mathrm{yr}^{-1}$ in throughfall in the greater Yellowstone area. The CLO of $3.1 \mathrm{~kg} \mathrm{~N} \mathrm{ha}^{-1} \mathrm{yr}^{-1}$ in throughfall has been proposed to protect the integrity of the lichen communities in the Pinus ponderosa forests of the Sierra Nevada (Fenn et al., 2008).

692 Geiser et al. (2010) proposed in turn a lichen-based CLO of $2.7 \mathrm{~kg} \mathrm{~N} \mathrm{ha}^{-1} \mathrm{yr}^{-1}$ for atmospheric $693 \mathrm{~N}$ deposition in Northwestern North America's maritime forests, with an annual mean precipitation of approximately $450 \mathrm{~mm}$. The $\mathrm{N}$ contents of $H$. physodes and/or $P$. glauca in Teijo and Pallas and the frequencies of N-sensitive epiphytes, as well as the frequency of green algae $+S$. chlorococcum in Teijo suggest a CLO of 2--3 $\mathrm{kg} \mathrm{N} \mathrm{ha}^{-1} \mathrm{yr}^{-1}$ in throughfall for 697 the northernmost conifer forests.

If $10 \mu \mathrm{g} \mathrm{NO}_{2} \mathrm{~m}^{-3}$ corresponds to $2.9 \mathrm{~kg} \mathrm{~N}^{-1} \mathrm{yr}^{-1}$ and $1 \mu \mathrm{g} \mathrm{NH} 3 \mathrm{~m}^{-3}$ to $2.6 \mathrm{~kg} \mathrm{~N} \mathrm{ha}^{-1} \mathrm{yr}^{-1}$ on short vegetation (Cape et al., 2004), setting the $\mathrm{NO}_{2} \mathrm{CLE}$ at $5 \mu \mathrm{g} \mathrm{m}^{-3} \mathrm{yr}^{-1}$ and that of $\mathrm{NH}_{3}$ at $0.5 \mu \mathrm{g} \mathrm{m}^{-3} \mathrm{yr}^{-1}$ would yield a total $\mathrm{N}$ deposition of approximately $3 \mathrm{~kg} \mathrm{~N} \mathrm{ha}^{-1} \mathrm{yr}^{-1}$. The total $\mathrm{N}$ deposition on epiphytic lichens beneath canopies may be higher (Hanson and Lindberg, 1991), however, and exceed the threshold, partly because organic $\mathrm{N}$ compounds are also 703 deposited on and leached from tree canopies (Carlisle et al., 1966, 1967; Piirainen et al., 704 1998). The uptake of amino acids by lichens may be equal to that of $\mathrm{NO}_{3}^{-}$(Dahlman et al., 705 2004). Thus, it is challenging to assess the contribution of dry, wet and occult deposition of 
different $\mathrm{N}$ forms to the lichen $\mathrm{N}$ content and community composition, especially in urban areas with various $\mathrm{N}$ sources, while also taking into account the modifying role of climatic 708 factors.

709

\section{Conclusions}

711 Air pollution in the Helsinki metropolitan area was associated with detrimental effects on 712 lichen community composition. Based on the frequencies of sensitive indicator species and $\mathrm{N}$ 713 contents of lichen thalli, CLEs of $5 \mu \mathrm{g} \mathrm{NO}_{2} \mathrm{~m}^{-3} \mathrm{yr}^{-1}$ and $0.5 \mu \mathrm{g} \mathrm{NH}_{3} \mathrm{~m}^{-3} \mathrm{yr}^{-1}$, and a CLO of 2--

$7143 \mathrm{~kg} \mathrm{~N} \mathrm{ha}^{-1} \mathrm{yr}^{-1}$ in throughfall are proposed to protect the biodiversity of acidophytic lichens 715 in boreal forests. Revision of the CLE for $\mathrm{SO}_{2}$ and the CLO for $\mathrm{S}$ deposition is also recommended. The present study calls for monitoring of $\mathrm{N}$ throughfall to gain a better understanding of the impact of atmospheric $\mathrm{N}$ pollution, especially dry deposition of $\mathrm{NO}_{\mathrm{x}}$ and particulate $\mathrm{N}$ pollutants, on lichen diversity in both urban and rural areas under different climates.

\section{Acknowledgements}

722 I thank the City of Helsinki (Timo Virtanen) and Metsähallitus (Henrik Johansson, Harri 723 Karjalainen, Pauliina Kulmala) for permission to conduct the study in the urban forests and 724 national parks, respectively. Laura Arppe and Hanna Turunen (Laboratory of Chronology, 725 Finnish Museum of Natural History - LUOMUS, University of Helsinki) are acknowledged 726 for the $\mathrm{N}$ isotope analysis, Marjut Wallner (Department of Forest Ecology, University of 727 Helsinki) for the total $\mathrm{C}$ and $\mathrm{N}$ analyses of the lichens and ICP analyses of the bark, and Riitta 728 Ilola and Jaakko Vainionpää (Lammi Biological Station, University of Helsinki) for the analyses of inorganic $\mathrm{N}$ fractions in bark. Financial support for the study was obtained from

730 the Department of Environmental Sciences, University of Helsinki. Two anonymous 731 reviewers are thanked for their good comments. Special thanks are dedicated to Dr Richard V. 732 Pouyat, USDA Forest Service, for sharing interest in this topic. The language was revised by 733 Roy Siddall, University of Helsinki.

\section{References}

736 Ahti, T., 1977. Lichens of the boreal coniferous zone, in: Seaward, M.R.D. (Ed.), Lichen 737 Ecology. Academic Press, London, pp. 145-181. 
Ammann, M., Siegwolf, R., Pichlmayer, F., Suter, M., Saurer, M., Brunold, C., 1999. Estimating the uptake of traffic-derived $\mathrm{NO}_{2}$ from ${ }^{15} \mathrm{~N}$ abundance in Norway spruce needles. Oecologia 118, 124-131.

Ashmore, M.R., Wilson, R.B., 1993. Critical levels of air pollutants for Europe. Background papers prepared for the ECE Workshop on critical levels, Egham, UK, 23-26 March 1992.

Bäcklund, S., Jönsson, M., Strengbom, J., Frisch, A., Thor, G., 2016. A pine is a pine and a spruce is a spruce - The effect of tree species and stand age on epiphytic lichen communities. PLoS ONE 11(1): e0147004. doi:10.1371/jpurnal.pone.0147004

Bates, J.W., Brown, D.H., 1981. Epiphyte differentiation between Quercus petraea and Fraxinus excelsior trees in a maritime area of South West England. Vegetatio 48, 61-70.

Bermejo-Orduna, R., McBride, J.R., Shiraishi, K., Elustondo, D., Lasheras, E., Santamaria, J.M., 2014. Biomonitoring of traffic-related nitrogen pollution using Letharia vulpina (L.) Hue in the Sierra Nevada, California. Science of the Total Environment 290, 205-212.

Bobbink, R., Hicks, K., Galloway, J., Spranger, T., Alkemade, R., Ashmore, M., Bustamente, 753 M., Cinderby, S., Davidson, E., Dentener, F., Emmett, B., Erisman, J.-W., Fenn, M., Gilliam, F., Nordin, A., Pardo, L., De Vries, W., 2010. Global assessment of nitrogen deposition effects on terrestrial plant diversity: a synthesis. Ecological Applications 20, $30-59$.

Bobbink, R., Hettelingh, J.-P. (Eds.) 2011. Review and revision of empirical critical loads and dose-response relationships. Proceedings of an expert workshop, Noordwijkerhout, 23-25

Braun, S., Achermann, B., De Marco, A., Pleijel, H., Karlsson, P.E., Rihm, B., Schindler, C., Paoletti, E., 2017. Epidemiological analysis of ozone and nitrogen impacts on vegetation Critical evaluation and recommendations. Science of the Total Environment 603-604, 785792.

Bruteig, I.E., 1993. The epiphytic lichen Hypogymnia physodes as a biomonitor of atmospheric nitrogen and sulphur deposition in Norway. Environmental Monitoring and Assessment 26, 27-47.

Cape, J.N., Tang, Y.S., van Dijk, N., Love, L., Sutton, M.A., Palmer, S.C.F., 2004. Concentrations of ammonia and nitrogen dioxide at roadside verges, and their contribution to nitrogen deposition. Environmental Pollution 132, 469-478.

Cape, J.N., van der Eerden, L.J., Sheppard, L.J., Leith, I.D., Sutton, M.A., 2009. Reassessment of critical levels for atmospheric ammonia, in: Sutton, M., Reis, S., Baker, 
S.M.H. (Eds.), Atmospheric ammonia. Springer Science + Business Medi B.V., Dordrecht, pp. 15-40.

773

774

775

776

777

778

779

780

781

782

783

784

785

786

787

788

789

790

791

792

793

794

795

796

797

Carlisle, A., Brown, A.H.F., White, E.J., 1966. The organic matter and nutrient elements in the precipitation beneath a sessile oak (Quercus petraea) canopy. Journal of Ecology 54, 87-98.

Carlisle, A., Brown, A.H.F., White, E.J., 1967. The nutrient content of tree stem flow and ground flora litter and leachates in a sessile oak (Quercus petraea) woodland. Journal of Ecology 55, 615-627.

City of Helsinki. Traffic volumes in Helsinki. https://www.avoindata.fi/data/en/dataset/liikennemaarat-helsingissa (accessed 18.05.2017).

CLRTAP, 2017. Mapping Critical Levels for Vegetation, Chapter III of Manual on methodologies and criteria for modelling and mapping critical loads and levels and air pollution effects, risks and trends. UNECE Convention on Long-range Transboundary Air Pollution. $\quad$ http://icpvegetation.ceh.ac.uk/publications/documents/Chapter3Mappingcriticallevelsforvegetation.pdf (accessed 14.04.2017).

Crittenden, P.D., 1998. Nutrient exchange in an Antarctic macrolichen during summer snowfall - snow melt events. New Phytologist 139, 697-707.

Dahlman, L., Näsholm, T., Palmqvist, K., 2002. Growth, nitrogen uptake, and resource allocation in the two tripartite lichens Nephroma arcticum and Peltigera aphthosa during nitrogen stress. New Phytologist 153, 307-315.

Dahlman, L., Persson, J., Nasholm, T., Palmqvist, K., 2003. Carbon and nitrogen distribution in the green algal lichens Hypogymnia physodes and Platismatia glauca in relation to nutrient supply. Planta, 217, 41-48.

Dahlman, L., Persson, J., Palmqvist, K., Näsholm, T., 2004. Organic and inorganic nitrogen uptake in lichens. Planta 219, 459-467.

Davies, L., Bates, J.W., Bell, J.N.B., James, P.W., Purvis, O.W., 2007. Diversity and sensitivity of epiphytes to oxides of nitrogen in London. Environmental Pollution 146, 299-310.

Denison, R., Caldwell, B., Bormann, B., Eldred, L., Swanberg, C., Anderson, S., 1977. The effects of acid rain on nitrogen fixation in western Washington coniferous forests. Water, Air, and Soil Pollution 8, 21-34.

de Vries, W., Kros, H., Reinds, G.J., Wamelink, W., Mol, J., van Dobben, H.F., Bobbink, R., Emmett, B., Smart, S., Evans, C., Schlutow, A., Kraft, P., Belyazid, S., Sverdrup, H., van Hinsberg, A., Posch, M., Hettelingh, J.P., 2007. Developments in deriving critical limits 
and modelling critical loads of nitrogen for terrestrial ecosystems in Europe. Alterra Report 1382. Wageningen University, The Netherlands, 206 p.

Elliott, E.M., Kendall, C., Wankel, S.D., Burns, D.A., Boyer, E.W., Harlin, K., Bain, D.J., Butler, T.J., 2007. Nitrogen isotopes as indicators of $\mathrm{NO}_{\mathrm{x}}$ source contributions to atmospheric nitrate deposition across the midwestern and northeastern United States. Environmental Science \& Technology 41, 7661-7667.

Elliott, E.M., Kendall, C., Boyer, E.W., Burns, D.A., Lear, G.G., Golden, H.E., Harlin, K., Bytnerowicz, A., Butler, T.J., Glatz, R., 2009. Dual nitrate isotopes in dry deposition: utility for partitioning $\mathrm{NO}_{\mathrm{x}}$ source contributions to landscape nitrogen deposition. Journal of Geophysical Research 114(G4):G04020.

Fenn, M.E., Jovan S., Yuan, F., Geiser, L., Meixner, T., Gimeno, B.S., 2008. Empirical and simulated critical loads for nitrogen deposition in California mixed conifer forests.

Environmental Pollution 155, 492-511.

818 Finnish Meteorological Institute. Air quality in Finland. Finnish Meteorological Institute and Ministry of the Environment. (http://www.ilmanlaatu.fi/index.php) accessed on 07.04.2017).

821 Finnish Meteorological Institute. Temperature and precipitation statistics from 1961 onwards. http://en.ilmatieteenlaitos.fi/statistics-from-1961-onwards (accessed on 07.04.2017).

823 Finnish Transport Agency. Maps and charts. Traffic volumes. 824 http://www.liikennevirasto.fi/web/en/maps-charts/traffic-volumes\#.WSFnbTMRrIE $825 \quad$ (accessed 18.05.2017).

826 Flechard, C.R., Nemitz, E., Smith, R.I., Fowler, D., Vermeulen, A.T., Bleeker, A., Erisman, 827 J.W., Simpson, D., Zhang, L., Tang, Y.S., Sutton, M.A., 2011. Dry deposition of reactive nitrogen to European ecosystems: a comparison of inferential models across the NitroEurope network. Atmospheric Chemistry and Physics 11, 2703-2728.

Gaio-Oliveira, G., Branquinho, C., Máguas, C., Martins-Loução, M.A., 2001. The concentration of nitrogen in nitrophilous and non-nitrophilous lichen species. Symbiosis 31, 187-199.

Gaio-Oliveira, G., Dahlman, L., Palmqvist, K., Martins-Loução, M.A., Máguas, C., 2005. Nitrogen uptake in relation to excess supply and its effects on the lichens Evernia prunastri (L.) Ach and Xanthoria parietina (L.) Th. Fr.. Planta 220, 794-803.

Gauslaa, Y., 1995. The Lobarion, an epiphytic community of ancient forests threatened by

838 Geiser, L.H., Neitlich, P.N., 2007. Air pollution and climate gradients in western Oregon and 
Washington indicated by epiphytic macrolichens. Environmental Pollution 145, 203-218.

Geiser, L.H., Jovan, S.E., Glavich, D.A., Porter, M.K., 2010. Lichen-based critical loads for atmospheric nitrogen deposition in Western Oregon and Washington Forests, USA. Environmental Pollution 158, 2412-2421.

Gilbert, O.L., 1973. Lichens and air pollution, in: Ahmadjian, V., Hale, M.E. (Eds.), The Lichens. Academic Press, New York, pp. 443-472

Giordani, P., Calatayud, V., Stofer, S., Seidling, W., Granke, O., Fischer, R., 2014. Detecting the nitrogen critical loads on European forests by means of epiphytic lichens. A signal-tonoise evaluation. Forest Ecology and Management 311, 29-40.

Gombert, S., Asta, J., Seaward, M.R.D., 2003. Correlation between the nitrogen concentration of two epiphytic lichens and the traffic density in an urban area. Environmental Pollution $123,281-290$.

Grandin, U., 2011. Epiphytic algae and lichen cover in boreal forests - A long-term study along a $\mathrm{N}$ and $\mathrm{S}$ deposition gradient in Sweden. AMBIO 40, 857-866.

Green, T.G.A., Horstmann, J., Bonnett, H., Wilkins, A., Silvester, W.B., 1980. Nitrogen fixation by members of the Stictaceae (lichens) of New Zealand. New Phytologist 84, 339348.

Gustafsson, L., Eriksson, I., 1995. Factors of importance for the epiphytic vegetation of aspen Populus tremula with special emphasis on bark chemistry and soil chemistry. Journal of Applied Ecology 32, 412-424.

Hale, M.E. Jr. 1968. A synopsis of the lichen genus Pseudevernia. The Bryologist 71, 1-11.

Hannuniemi, H., Salmi, J., Rasila, T., Wernberg, A., Komppula, B., Lovén, K., Pietarila, H., 2016. Pääkaupunkiseudun päästöjen leviämismalliselvitys. Autoliikenteen, energiantuotannon, laivaliikenteen ja lentoliikenteen typenoksidi-, pienhiukkas- ja rikkidioksidipäästöjen leviämismallinnus. Ilmatieteen laitos.

Hanson, P.J., Lindberg, S.E., 1991. Dry deposition of reactive nitrogen compounds: A review of leaf, canopy and non-foliar measurements. Atmospheric Environment 25, 1615-1634.

Hauck, M., Runge, M., 2002. Stemflow chemistry and epiphytic lichens diversity in diebackaffected spruce forest of the Harz Mountains, Germany. Flora 197, 127-131.

Hauck, M., Hesse, V., Runge, M., 2002. The significance of stemflow chemistry for epiphytic lichens diversity in dieback-affected spruce forest on Mt. Brocken, northern Germany. Lichenologist 34, 415-427.

Hauck, M., 2011. Site factors controlling epiphytic lichen abundance in northern coniferous

$$
\text { forests. Flora 206, 81-90. }
$$


873 Heaton, T.H.E., Spiro, B., Robertson, S.M.C., 1997. Potential canopy influences on the 874 isotopic composition of nitrogen and sulphur in atmospheric deposition. Oecologia 109, $875 \quad 600-607$.

876 Högberg, M., Myrold, D.D., Giesler, R., Högberg, P., 2006. Contrasting patterns of soil N877 cycling in model ecosystems of Fennoscandian Boreal Forests. Oecologia. 147, 96-107.

878 Honegger, R., 1991. Functional aspects of the lichen symbiosis. Annual Review of Plant 879 Physiology and Plant Molecular Biology 42, 553-578.

880 Honegger, R., 1993. Developmental biology of lichens. New Phytologist 125, 659-677.

881 Honegger, R. 1998. The lichen symbiosis - What is so spectacular about it? Lichenologist 30, 882 193-212.

883

Howarth, R.W., 2007. Atmospheric deposition and nitrogen pollution in coastal marine 884 885 ecosystems, in: Visgilio, G.R., Whitelaw, D.M. (Eds), Acid in the Environment. Springer, Boston, MA. pp. 97-116.

Johansson, O., Nordin, A., Olofsson, J., Palmqvist, K., 2010. Responses of epiphytic lichens 888 to an experimental whole-tree nitrogen deposition gradient. New Phytologist 188, 10751084.

Johansson, O., Olofsson, J., Gielesr, R., Palmqvist, K., 2011. Lichen responses to nitrogen and phosphorus addition can be explained by the different symbiont responses. New Phytologist 191, 795-805.

892

Johansson, O., Palmqvist, K., Olofsson, J., 2012. Nitrogen deposition drives lichen 893 community changes through differential species responses. Global Change Biology 18, 2626-2635.

Jovan, S., Riddell, J., Padgett, P.E., Nash, T.H. III. 2012. Eutrophic lichens respond to multiple forms of $\mathrm{N}$ : implications for critical levels and loads research. Ecological Applications 22, 1910-1922.

Karl, T., Graus, M., Stridnig, M., Lamprecht, C., Hammerle, A., Wohlfahrt, G., Held, A., von der Heyden, L., Deventer, M.J., Krismer, A., Haun, C., Feichter, R., Lee, J., 2017. Urban eddy covariance measurements reveal significant missing $\mathrm{NO}_{\mathrm{x}}$ emissions in Central Europe. Nature Scientific Reports 7: 2536. doi:10.1038/s41598-017-02699-9

Kaski, N., Aarnio, P., Loukkola, K., Portin, H., 2016. Air quality in the Helsinki metropolitan area in 2015. HSY publications 6/2016. Helsinki Region Environmental Services Authority.

Krouse, H.R., 1977. Sulphur isotope abundance elucidate uptake of atmospheric sulphur emissions by vegetation. Nature 252, 45-46. 
Kuusinen, M., 1996. Epiphytic flora and diversity on basal trunks of six old-growth forest tree species in southern and middle boreal Finland. Lichenologist 28, 443-463.

Lang, G.E., Reiners, W.A., Heier, R.K., 1976. Potential alteration of precipitation chemistry by epiphytic lichens. Oecologia 25, 229-241.

Larsen, R.S., Bell, J.N.B., James, P.W., Chimonides, P.J., Rumsey, F.J., Tremper, A., Purvis, O.W., 2007. Lichen and bryophyte distribution on oak in London in relation to air pollution and bark acidity. Environmental pollution 146, 332-340.

914

Larsen Vilsholm, R., Wolseley, P.A., Søchting, U., Chimonides, P.J., 2009. Biomonitoring with lichens on twigs. The Lichenologist 41, 189-202.

916

Levia Jr., D.F., 2002. Nitrate sequestration by corticulous macrolichens during winter precipitation events. International Journal of Biometeorology 46, 60-65.

918

Lindroos, A-J., Derome, K. and Nieminen, T. M., 2013. Sulphur and nitrogen deposition in bulk deposition and stand throughfall on intensive monitoring plots in Finland, in: Merilä, P., Jortikka, S. (Eds.), Forest Condition Monitoring in Finland - National report. The Finnish Forest Research Institute. http://urn.fi/URN:NBN:fi:metla-201305087576 (accessed 13.01.2017).

924

Lovett, G.M., Traynor, M.M., Pouyat, R.V., Carreiro, M.M., Zhu, W.-X., Baxter, J.W., 2000. Atmospheric deposition to oak forests along an urban rural gradient. Environmental Science \& Technology 34, 4294-4300.

927

928

Manninen, S., Sassi, M-K., Lovén, K. 2013. Effects of nitrogen oxides on ground vegetation, Pleurozium schreberi and the soil beneath it in urban forests. Ecological Indicators 24, 485-493.

McMurray, J.A., Roberts, D.W., Fenn, M.E., Geiser, L.H., Jovan, S., 2013. Using epiphytic

Mitchell, R.J., Truscot, A.M., Leith, I.D., Cape, J.N., van Dijk, N., Tang, Y.S., Fowler, D., Sutton, M.A., 2005. A study of the epiphytic communities of Atlantic oaks woods along an atmospheric nitrogen deposition gradient. Journal of Ecology 93, 482-492.

Munzi, S., Pisani, T., Paoli, L., Loppi, S., 2010. Time- and dose-dependency of the effects of nitrogen pollution on lichens. Ecotoxicology and Environmental Safety 73, 1785-1788. ammonia tolerance amongst lichen functional groups be explained by physiological responses? Environmental Pollution 187, 206-209. 
941 Nieboer, E., Richarsson, D.H.S., Tomassini, F.D., 1978. Mineral uptake and release by

942

943

944

945

946

947

948

949

950

951

952

953

954

955

956

957

958

959

960

961

962

963

964

965

966

967

968

969

970

971

972

973 lichens: an overview. The Bryologist 81, 226-246.

Palmqvist, K., 2000. Tansley review No. 11. Carbon economy in lichens. New Phytologist $148,11-36$.

Palmqvist, K., Dahlman, L., Valladares, F., Tehler, A., Sancho, L.G., Mattson J.-E., 2002. $\mathrm{CO}_{2}$ exchange and thallus nitrogen across 75 contrasting lichen associations from different climate zones. Oecologia 133, 295-306.

Palmqvist, K., Dahlman, L., 2006. Responses of the green algal foliose lichen Platismatia glauca to increased nitrogen supply. New Phytologist 171, 343-356.

Pardo, L.H., Geiser, L.H., Fenn, M.E., Driscoll, C.T., Goodale, C.L., Allen, E.B., Baron, J.S., Bobbink, R., Bowman, W.D., Clark, C.M., Emmett, B., Gilliam, F.S., Greaver, T., Hall, S.J., Lilleskov, E.A:, Liu, L., Lynch, J.A., Nadelhoffer, K., Perakis, S.S., Robin-Abbott, M.-J., Stoddard, J.L., Weathers, K.C., 2011a. Synthesis, in: Pardo, L.H., Robin-Abbott, M.J., Driscoll, C.T. (Eds.), Assessment of nitrogen deposition effects and empirical critical loads of nitrogen for ecoregions of the United States. General Technical Report NRS-80. USDA Forest Service, Northern Research Station, Newtown Square, Pennsylvania, USA. pp. 229-284.

Pardo, L.H., Fenn, M.E., Goodale, C.L., Geiser, L.H., Driscoll, C.T., Allen, E.B., Baron, J.S., Bobbink, R., Bowman, W.D., Clark, C.M., Emmett, B., Gilliam, F.S., Greaver, T.L., Hall, S.J., Lilleskov, E.A:, Liu, L., Lynch, J.A:, Nadelhoffer, K.J., Perakis, S.S., Robin-Abbott, M.J., Stoddard, J.L., Weathers, K.C., Dennis, R.L., 2011b. Effects of nitrogen deposition and empirical nitrogen loads for ecoregions of the United States. Ecological applications 21, 3049-3082.

Pearson, J., Wells, D.M., Seller, K.J., Bennett, A., Soares, A., Woodall, J., Ingrouille, M.J., 2000. Traffic exposure increases natural ${ }^{15} \mathrm{~N}$ and heavy metal concentrations in mosses. New Phytologist 147, 317-326.

Piirainen. S., Finér, L., Starr, M., 1998. Canopy and soil retention of nitrogen deposition in a mixed boreal forest in Eastern Finland. Water, Air , and Soil Pollution 105, 165-174.

Pike, L.H., 1978. The importance of epiphytic lichens in mineral cycling. The Bryologist 81, 247-267.

Pinho, P., Llop, E., Ribeiro, M.C., Cruz, C., Soares, A., Pereira, M.J., Branquinho, C., 2014. Tools for determining critical levels of atmospheric ammonia under the influence of multiple disturbances. Environmental Pollution 188, 88-93. 
974 Poikolainen, J., Lippo, H., Hongisto, M., Kubin, E., Mikkola, K., Lindgren, M., 1998. On the

975

976

977

978

979

980

981

982

983

984

985

986

987

988

989

990

991

992

993

994

995

996

997

998

999

1000

1001

1002

1003

1004

1005

1006

1007 abundance of epiphytic green algae in relation to the nitrogen concentrations of biomonitors and nitrogen deposition in Finland. Environmental Pollution 102, S1, 85-92.

Purvis, O.W., Chimonides, P.J., Din, V., Erotokritou, L., Jeffries, T.E., Jones, G.C., Louwhoff, S., Read, H., Spiro, B., 2003. Which factors are responsible for the changing lichen floras of London. The Science of the Total Environment 310, 179-189.

Rao, D.N., LeBlanc, F., 1966. Effects of sulphur dioxide on the lichen alga, with special reference to chlorophyll. The Bryologist 69, 69-75.

Rao, P., Hutyra, L.R., Raciti, S.M., Templer, P.H., 2014. Atmospheric nitrogen deposition inputs and losses along an urbanization gradient from Boston to Harvard Forest, MA. Biogeochemistry 121, 229-245.

Redling, K., Elliott, E., Bain, D., Sherwell, J., 2013. Highway contributions to reactive nitrogen deposition: tracing the fate of vehicular $\mathrm{NO}_{\mathrm{x}}$ using stable isotopes and plant biomonitors. Biogeochemistry 116, 261-274.

Root, H.T., Geiser, L.H., Fenn, M.E., Jovan, S., Hutten, M.A., Ahuja, S., Dillman, K., Schirokauer, D., Berryman, S., McMurray, J.A. 2013. A simple tool for estimating throughfall nitrogen deposition in forests of western North America using lichens. Forest Ecology and Management 306, 1-8.

Ruoho-Airola, T., Anttila, P., Hakola, H., Ryyppö, T., Tuovinen, J.-P., 2015. Trends in the bulk deposition and atmospheric concentration of air pollutants in the Finnish Integrated Monitoring catchment Pallas during 1992-2012. Boreal Environment Research 20, 553569.

Schultz, H., Huhn, G., Shüürmann, G., Niehus, B., Liebergeld, G., 1997. Determination of throughfall rates on the basis of pine bark loads, results of a pilot field study. Journal of the Air \& Waste Management Association 47, 510-516.

Schultz, H., Popp, P., Huhn, G., Stärk, H.-J., Schüürmann, G., 1999. Biomonitoring of airborne inorganic and organic pollutants by means of pine tree barks. I. Temporal and spatial variations. The Science of the Total Environment 232, 49-58.

Schmull, M., Hauck, M., Vann, D.R., Johnson, A.H., Runge, M., 2002. Site factors determining epiphytic lichen distribution in a dieback-affected spruce-fir forest on Whiteface Mountain, New York: stemflow chemistry. Canadian Journal of Botany 80, 1131-1140.

SFS-EN ISO 11732. Water quality. Determination of ammonium nitrogen. Method by flow analysis (CFA and FIA) and spectrometric detection (ISO 11732:2005). 
SFS-EN ISO 13395. Water quality. Determination of nitrite nitrogen and nitrate nitrogen and the sum of both by flow analysis (CFA and FIA) and spectrometric detection (ISO 13395:1996)

Skye, E., 1968. Lichens and air pollution. A study of cryptogamic epiphytes and environment in the Stockholm region. Acta Phytogeographica Suecica 52, 1- 123.

Skye, E., Hallberg, I., 1969. Changes in lichen flora following air pollution. Oikos 20, 547552.

Søchting, U., 1995. Lichens as monitors of nitrogen deposition. Cryptogamic Botany 5, 264269.

Suomen standardisoimisliitto 1990. SFS standard 5670. Air quality. Bioindication. Mapping of epiphytic lichens. (in Finnish)

Sutton, M.A., Dragosits, U., Tang, Y.S., Fowler, D. 2000. Ammonia emissions from nonagricultural sources in the UK. Atmospheric Environment 34, 855-869.

Taipale, L., 2006. Rikkidioksipitoisuudet alas korkeilla piipuilla - Hanasaari B, in: Huutoniemi, K., Estlander, A., Hahkala, M., Hämekoski, K., Kulmala, A., Lahdes, R., Laukkanen, T. (toim.), Savuntarkastajista päästökauppiaisiin. Suomalaisen ilmansuojelun historia. Gummerus, Jyväskylä, pp.74-75.

Teinilä, K., Aurela, M., Saarikoski, S., Timonen, H., Hillamo, R., Niemi, J., Kousa, A., 2016. Composition and sources of fine particles at a busy traffic environment in Helsinki city center. Helsinki Region Environmental Services Authority. HSY Publications 7/2016. (https://www.hsy.fi/sites/Esitteet/EsitteetKatalogi/Julkaisusarja/7_2016_pienhiukkastenkoostumus-lahteet.pdf)

Thell, A., Moberg, R., 2011. Nordic Lichen Flora. Vol. 4. Parmeliaceae. Uppsala, Uppsala University, Nordic Lichen Society.

Tørseth, K., Aas, W., Breivik, K., Fjæraa, A.M., Fiebig, M., Hjellbrekke, A.G., Lund Myhre, C., Solberg, S., Yttri, K.E., 2012. Introduction to the European Monitoring and Evaluation Programme (EMEP) and observed atmospheric composition change during 1972-2009. Atmospheric Chemistry and Physics 12, 5447-5481.

Vaarna, V.V., 1934. Helsingin kaupungin puiden ja pensaiden jäkäläkasvisto. Annales Botanici Societatis zoologicæ-botanicæ Fennicæ Vanamo 5, 1-32.

van Dobben H.F., Ter Braak, C.J.F., 1998. Effects of atmospheric $\mathrm{NH}_{3}$ on epiphytic lichens in the Netherlands: the pitfalls of biological monitoring. Atmospheric Environment 32, 551557. 
1041 van Herk, C.M., 1999. Mapping ammonia pollution with epiphytic lichens in the Netherlands. 1042 Lichenologist 31, 9-20.

1043 van Herk, C.M., 2001. Bark pH and susceptibility to toxic air pollutants as independent 1044 causes of changes in epiphytic lichen composition in space and time. Lichenologist 33, 1045 419-441.

1046 van Herk, K. 2004. A changing flora, the effects of short and long distance nitrogen 1047 deposition on epiphytic lichens, in: Lambley, P., Wolseley, P. (Eds.), Lichens in a 1048 Changing Pollution Environment. English Nature, Peterborough, UK. English Nature 1049 research Reports No. 525. pp. 13-20.

1050 Wolterbeek, T.Th., Kuik, P., Verburg, T.G., Wamelink, G.W.W., 1996. Relations between 1051 sulphate, ammonia, nitrate, acidity and trace element concentrations in tree bark in the 1052 Netherlands. Environmental Monitoring and Assessment 40, 185-201. 


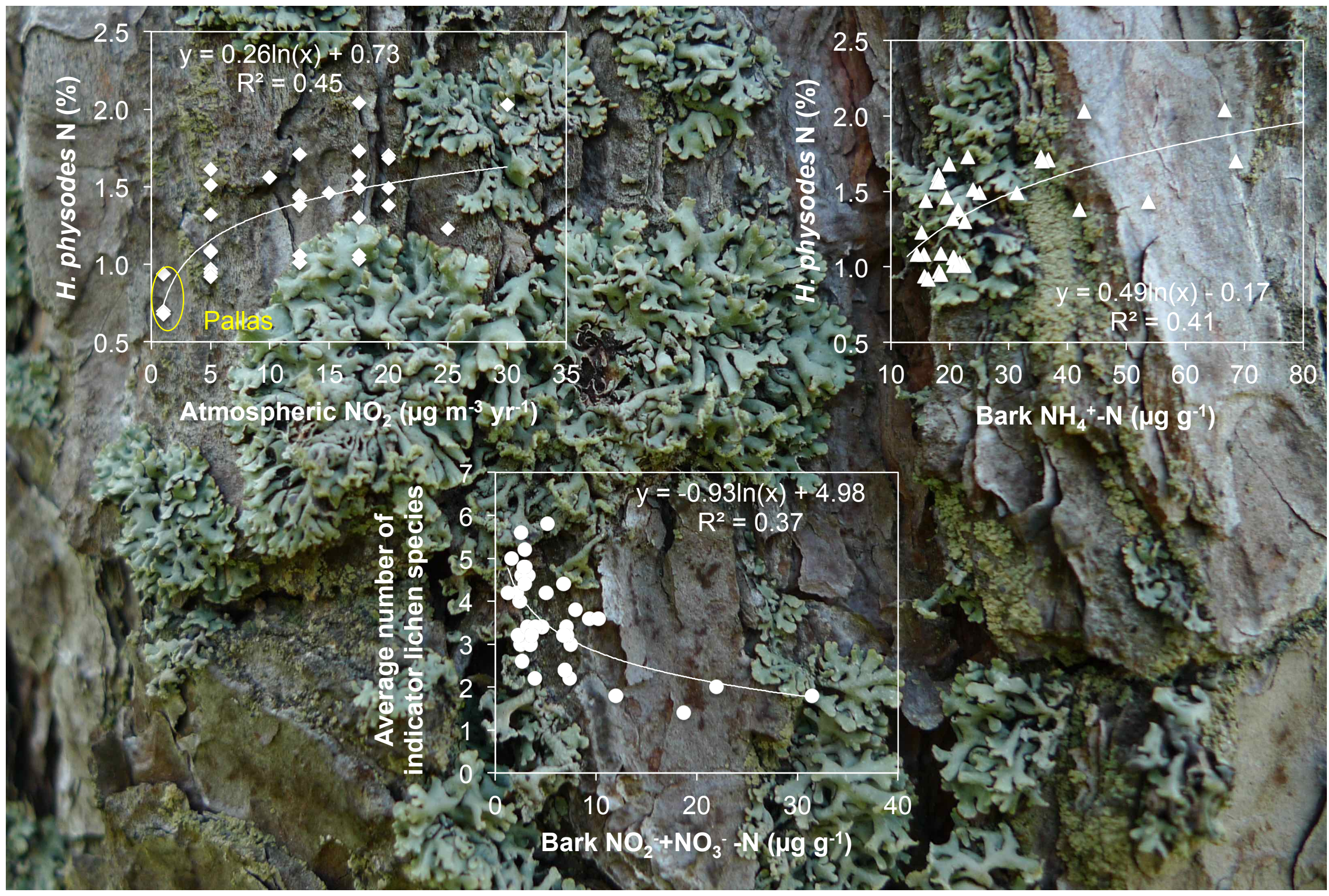

Responses of acidophytes growing on Pinus sylvestris trunks to reactive $\mathrm{N}$ compounds in their environment in the Helsinki metropolitan area and/or Pallas National Park. Damaged Hypogymnia physodes, air-pollutant-tolerant Hypocenomyce scalaris and green algae + Scoliciosporum chlorococcum in the background (photo S. Manninen). 